Hydrol. Earth Syst. Sci. Discuss., 8, 1665-1704, 2011 www.hydrol-earth-syst-sci-discuss.net/8/1665/2011/ doi:10.5194/hessd-8-1665-2011

(c) Author(s) 2011. CC Attribution 3.0 License.
Hydrology and Earth System Sciences Discussions

\title{
Rainfall estimation over the Wadi Dhuliel arid catchment, Jordan from GSMaP_MVK+
}

\section{E. Abushandi and B. Merkel}

Technische Universität Bergakdemie Freiberg, Geology Department, Gustav-Zeuner-Str. 12, 09596 Freiberg, Germany

Received: 15 January 2011 - Accepted: 29 January 2011 - Published: 4 February 2011

Correspondence to: E. Abushandi (eyadshandi@yahoo.com)

Published by Copernicus Publications on behalf of the European Geosciences Union.

\section{HESSD}

$8,1665-1704,2011$

Rainfall estimation over the Wadi Dhuliel arid catchment

E. Abushandi and

B. Merkel

\section{Title Page}

Abstract

Introduction

Conclusions

References

Tables

Figures

14

$>$ I

Back

Close

Full Screen / Esc

Printer-friendly Version

Interactive Discussion 


\section{Abstract}

The GSMaP_MVK+ (Global Satellite Mapping of Precipitation) dataset was used to evaluate the precipitation rates over the Wadi Dhuliel arid catchment in Northeast Jordan for the period of January 2003 to March 2008. The scarcity of the ground 5 rain gauge network alone did not adequately show the detailed structure of the rainfall distribution, independent form interpolation techniques used. This study combines GSMaP_MVK + and ground rain gauges to produce accurate, high-resolution datasets. Three meteorological stations and six rain gauges were used to adjust and compare GSMaP_MVK + estimates. Comparisons between GSMaP_MVK+ measurements and ground rain gauges records showed distinct regions where they correlate, as well as areas where GSMaP_MVK + systematically over- and underestimated ground rain gauge records. A multiple linear regression (MLR) model was used to derive the relationship between rainfall and GSMaP_MVK + in conjunction with temperature, relative humidity, and wind speed. The MLR equations were defined for the three meteorological sta15 tions. The "best" fit of MLR model for each station was chosen and used to interpolate a multiscale temporal and spatial distribution. Results show that the rainfall distribution over the Wadi Dhuliel is characterized by clear west-east and north-south gradients. Estimates from the monthly MLR model were more reasonable than estimates obtained using daily data. The adjusted GSMaP_MVK+ performed well in capturing the spatial patterns of the rainfall at monthly and annual time scales while daily estimation showed some weakness in light and moderate storms.

\section{Introduction}

Jordan has one of the world's lowest levels of available water resources (WHO). Due to this scarcity, Jordanian scientists and politicians have taken an increasingly active role in studying and managing water within Jordan during the last decade. Around $91 \%$ of Jordan lies on arid and semi-arid ground, which receive less than $200 \mathrm{~mm}$ of annual
HESSD

$8,1665-1704,2011$

Rainfall estimation

over the Wadi Dhuliel arid catchment

E. Abushandi and

B. Merkel

Title Page

Abstract

Introduction

Conclusions

Tables

Figures

14

4

Back

Close

Full Screen / Esc

Printer-friendly Version

Interactive Discussion 
rainfall (Fig. 1). Precipitation occurs primarily as rainfall with relatively high intensity in limited range of space and time. Since precipitation is Jordan's first source of water, it is important to investigate and analyze the rainfall behaviour.

The rainfall distribution in Jordan varies with location mainly due to arid climate at5 tribute and topographic variations. Rainfall controls domestic and agricultural activities, especially in the rural area where the percentages of water use are $31 \%$ and $65 \%$, respectively (FAO, 2005). In comparison to other Middle Eastern countries, Jordan has the lowest magnitude of annual rainfall coincident with high evaporation rates.

Rainfall is also the most important input parameter in rainfall runoff models (Beven, 10 2001; Croke and Jakeman, 2007), groundwater recharge models (Abdulla and AlAssa'd, 2006; Merkel and Sperling, 1993), climate change scenarios (Dolman and Gregory, 1994) and hydro-chemical models (Brezonik and Stadelmann, 2002). Additionally, rainfall information is a critical component in efficient management of urban drainage systems (Vieux and Vieux, 2005). Consequently, an accurate assessment of rainfall variability is essential to reduce models uncertainty in the input data of these models.

Due to the arid climate, topographic variations, and a complicated land cover structure temporal and spatial rainfall distributions in Jordan are characterized by a high degree of variability. The annual rainfall magnitudes distinctly include a sharp west-east gradient from relatively wet west regions with about $600 \mathrm{~mm}$ per year, to the Jordanian desert (Al-Badia), with rainfall less than $100 \mathrm{~mm}$ per year.

The surface water resources and ground water recharges in the country depend on the magnitude of yearly rainfall. The total annual rainfall on Jordan is approximately $8500 \times 10^{6} \mathrm{~m}^{3}$ (Abu-Zreig et al., 2000). According to the Jordan Ministry of Water and Irrigation (JMWI), the majority of the rainfall is lost through evapotranspiration $(87.9 \%), 8.5 \%$ is groundwater recharge, while the smallest portion is surface runoff (3.6\%) (Fig. 2a). These distributions are slightly different in drier regions of Northeast Jordan (Fig. 2b).
HESSD

$8,1665-1704,2011$

Rainfall estimation

over the Wadi Dhuliel arid catchment

E. Abushandi and

B. Merkel

Title Page

Abstract

Introduction

Conclusions

Tables

Figures

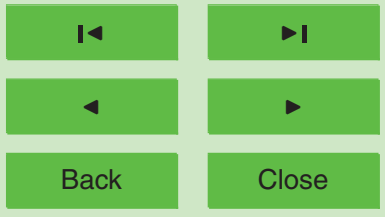

Full Screen / Esc

Printer-friendly Version

Interactive Discussion 
Rainfall temporal analysis may include rainfall periodicity (Gajiccapka, 1994), risk of drought (Akhtari et al., 2009; Pal and Al-Tabbaa, 2009; Wong et al., 2010), chance of rain and frequency (Goldreich, 1995), and time series analyses (Momani, 2009). In contrast, spatial rainfall analysis focuses on the rainfall distribution within a watershed.

5 Many different rainfall interpolation methods, such as Arithmetic Average, Isotheral method, and the Grid method are employed in current scientific literature. Thiessen polygons are the simplest interpolation method to estimate areal rainfall at a sample point (Thiessen, 1911).

These methods may not be the optimal to estimate the temporal and spatial rainfall 10 changes in arid regions without additional information or techniques. In some cases,
these methods were included in a hybrid approach that utilized other datasets and
techniques in order to ensure output quality or to avoid rainfall observation scarcity.

A relatively limited number of rainfall analysis techniques have been developed and modified for arid and semi-arid environments. Perhaps the earliest published research 15 on rainfall magnitudes analysis in arid regions was performed by Winkwort (1967) in Australia and Osborn and Hickok (1968) in the United States. Generally, the few published studies available from Jordan have tried to analyze rainfall characteristics in the entire country, rather than for individual catchments (Freiwan and Kadioglu, 2008; Tarawneh and Kadioglu, 2003), even though many arid drainage basins might be smaller than $10 \mathrm{~km}^{2}$ (Pilgrim et al., 1988).

Two studies have focused on the techniques of optimizing the number and location of rain gauges (Manik and Sidle, 2003; Tarawneh and Kadioglu, 2003). Comprehensive surface hydrology studies including rainfall characteristics with respect to temporal and spatial variability have been carried out in Jordan for the last decade. Some of these studies examined the changes of rainfall temporal patterns only; other cases analyze both spatial and temporal patterns.

In 2009, Momani analyzed the monthly rainfall temporal variation by applying ARIMA time series analysis to data recorded at the Amman airport. In order to achieve a proper rainfall forecast of his research, ARIMA model parameters were adjusted (Momani,
HESSD

$8,1665-1704,2011$

Rainfall estimation

over the Wadi Dhuliel arid catchment

E. Abushandi and

B. Merkel

Title Page

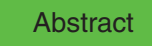

Introduction

Conclusions

Tables

References

Figures

14

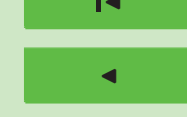

Back

Close 
2009).

Smadi and Zghoul (2006) examined the recent rainfall temporal trends and fluctuations for three meteorological stations, Amman, Madaba, and Al-Mafraq. They observed a direct interrelationship between rainfall levels at these stations.

5 Dahamsheh and Aksoy (2007) studied the structural characteristics of annual precipitation data for 13 meteorological stations distributed across Jordan and utilized the Isohyetal method to plot rainfall distribution. They employed a number of tests, such as consistency, randomness, best-fit distribution, and others in order to characterize the annual precipitation. There was no evidence of negative or positive precipitation trends 10 at any station. However, these results can not be directly compared with previous studies.

Tarawneh and Kadiolgu (2003) selected seventeen meteorological stations corresponding to different climatic regions of Jordan in order to depict spatial monthly precipitation characteristics. The frequency amplitude, periodicity phase angle, and basic 15 statistical parameters from the meteorological stations were calculated as steps of harmonic analysis of the precipitation. The results showed that the variance percentage of harmonic analysis is changing rapidly by moving to the east.

According to the results of local studies water harvesting is one possible future solution to capture and store rainfall in Jordan (Abu-Zreig et al., 2000; AbuAwwad and 20 Shatanawi, 1997; Oweis and Taimeh, 1995). In order to achieve highest efficiencies, a thorough knowledge of rainfall distribution is essential.

Spatial rainfall analysis requires a network of rain gauges or meteorological stations. The accuracy of spatial rainfall interpolation method depends on the density distribution and the distance between rainfall rain gauges. Frequently, rain gauge density is not 25 sufficient in arid regions (Pilgrim et al., 1988), leading to biased analyses of rainfall temporal and spatial distributions at the catchment scale. State-of-the-art techniques may solve this issue by matching precipitation data from ground-based rain gauges and high-resolution satellites in hybrid interpolation analysis.

HESSD

$8,1665-1704,2011$

\section{Rainfall estimation \\ over the Wadi Dhuliel arid catchment \\ E. Abushandi and \\ B. Merkel}

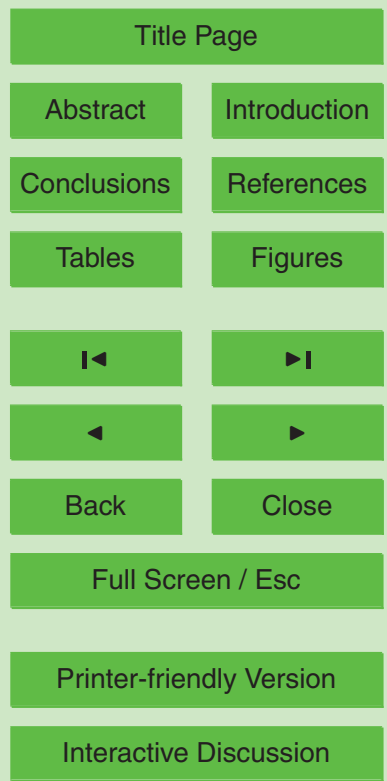


Recently, a number of global precipitation systems have been developed to meet scientific demand, such as PERSIANN (Sorooshian et al., 2000), Global Precipitation Climatology Project (GPCP) (Adler et al., 2000; Huffman et al., 2001; Xie et al., 2003), and multi-satellite precipitation analysis (TMPA) (Huffman et al., 2007).

5 Global or near-global satellite datasets are important to identify temporal and spatial rainfall changes in arid regions. Global Satellite Mapping of Precipitation (GSMaP) is based on passive microwave radiometer data and has shown to be effective for accurately estimating rainfall rate in $\mathrm{mm} \mathrm{h}^{-1}$ (Ushio et al., 2009). GSMaP combines precipitation retrievals from polar-orbiting satellites and cloud motion vectors derived 10 from infrared images. GSMaP_MVK+ uses four different types of satellite sensors as shown in Table 1 and an algorithm combining the CMORPH technique and Kalman filter (Tian et al., 2010).

The aim of this paper is to investigate rainfall characteristics of the Wadi Dhuliel catchment in Northeastern Jordan by utilizing GSMaP data and ground based rain gauge data. Moreover, this study aims to develop a technique to adjust the GSMaP data by means of rain gauge data and standard interpolation techniques to perceive a good understanding of rainfall variability in arid regions, reduce the potential errors of rain gauge estimates, and produce improved catchment scale rainfall distribution maps.

\section{Materials and methods}

\subsection{Study area description}

The Wadi Dhuliel is an appropriate example of an arid catchment in which rainfall and rainfall intensity varies significantly both with with time and space. The total area of the Wadi Dhuliel is approximately $1985 \mathrm{~km}^{2}$ and is located in northeast of Jordan. Most of the catchment area belongs to the Al-Zarqa river basin. Around $10 \%$ of the upper part of Wadi Dhuliel catchment passes over the Syrian border (Fig. 3). The altitude in the
HESSD

$8,1665-1704,2011$

Rainfall estimation

over the Wadi Dhuliel arid catchment

E. Abushandi and

B. Merkel

Title Page

Abstract

Introduction

Conclusions

Tables

References

Figures

14

4

Back

Full Screen / Esc

Printer-friendly Version

Interactive Discussion 
area is characterized by a very gentle undulating topography varying between $512 \mathrm{~m}$ in the southwest to $1400 \mathrm{~m}$ in the north.

Rainfall temporal magnitude in the Wadi Dhuliel tends to vary markedly from year to year with an irregular distribution over the year. As an example of the extreme 5 yearly variability in Wadi Dhuliel one rain gauge measured the annual rainfall to be $275.7,93.1,111.1,230.4,194.8,63.1$, and $209.5 \mathrm{~mm}$ over seven years. In one single day, a $62 \mathrm{~mm}$ rainfall event occurred, though the total annual rainfall in the same year was $100 \mathrm{~mm}$ (Sukhnah rain gauge). These kinds of rainfall events can easily generate significant surface runoff, resulting in severe soil erosion. Weather behaviour and 10 topographical aspects play important roles in this variation.

The region has essentially an arid climate with cold, rainy winter and a hot, dry summer. The average monthly rainfall showed that around $73 \%$ of the annual rainfall occurs during November, December, January, and February (Fig. 4).

Almafraq station has the highest rainfall magnitudes per annum with $158 \mathrm{~mm}$, Qasr 15 Al-Hallabat station has the lowest rainfall with $79.2 \mathrm{~mm}$. Overall, the annual rainfall is around $123 \mathrm{~mm}$ on average. In addition, the lowest temperatures are also during the winter months, with an average annual temperature (1976-2005) of $16.8^{\circ} \mathrm{C}$ (Fig. 5).

\subsection{Data and method of data analysis}

The datasets used in this work included ground rainfall data of nine gauging stations 20 at daily, monthly, and annual time steps between January 2003 and March 2008. A complementary Global Satellite Mapping of Precipitation dataset, currently known as GSMaP_MVK+ version 4.8.4 (short for GSMaP moving vector with Kalman filter method), was also examined.

The rain gauges dataset (Table 2) was gathered from the Surface Water Resources 25 Unit at the Jordan Ministry of Water and Irrigation (JMWI), and the Jordan Meteorological Department (JMD). Eight rain gauges are distributed in and near to Wadi Dhuliel I, and one station is located in Wadi Dhuliel II (Fig. 7). Almafraq meteorological station
HESSD

8, 1665-1704, 2011

Rainfall estimation

over the Wadi Dhuliel arid catchment

E. Abushandi and

B. Merkel

Title Page

Abstract

Introduction

Conclusions

Tables

References

Figures

14

4

Back

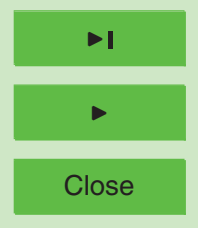

Full Screen / Esc

Printer-friendly Version

Interactive Discussion 
has records only until 2005 . However, only these nine stations produced a sufficient length of reliable data appropriate for this study.

The Global Satellite Mapping of Precipitation (GSMaP) project started in 2002 with support of the Japan Science and Technology Agency (Ushio et al., 2009). A frame 5 from $31.95^{\circ} \mathrm{N}-32.55^{\circ} \mathrm{N}$ and $36.15^{\circ} \mathrm{E}-36.85^{\circ} \mathrm{E}$ was extracted from the GSMaP_MVK+ dataset to cover the entire Wadi Dhuliel catchment area with 64 knots $(8 \times 8)$ and a spatial resolution of $10.8 \mathrm{~km}$ (Fig. 7). Based on the altitudes, rainfall magnitudes, and land cover characteristics, the area was divided into two distinct sub-catchments Wadi Dhuliel I and Wadi Dhuliel II.

10 Rainfall ground dataset was based upon the acquisition period of GSMaP_MVK+ data, from January 2003 to April 2008. In order to assess at which time scale the GSMaP_MVK+ estimates have sufficient match, the daily datasets from the GSMaP_MVK+ and ground rain gauging station were aggregated to monthly and annual records.

15 For the comparison between ground rain gauges and GSMaP_MVK+ datasets values of all ground rain gauge station were calculated from the four neighbouring GSMaP_MVK+ knots using inverse distance weighting (IDW) interpolation method.

\section{GSMaP_MVK+ measurements adjustment with ground rain gauges}

Since the GSMaP_MVK+ algorithm has been developed for precipitation over tropical and subtropical regions (Iwasaki, 2009); ground observations are required to adjust the satellite information. Furthermore, the input data to the GSMaP_MVK+ is based upon brightness temperature and cloud microphysical properties, and therefore gives relatively indirect information about rainfall rate. This adjustment process is needed to tune the residuals between local observation datasets and GSMaP_MVK+ estimates.

The adjustment process was based on remapping GSMaP_MVK+ pixel values with respect to rain gauge observations. Datasets from three meteorological stations were used to adjust GSMaP_MVK+ dataset. Khirebit Es Samra and Um-Jimal meteorological stations provide monthly rainfall, temperature, and wind speed data sets from 2003

\section{HESSD}

$8,1665-1704,2011$

Rainfall estimation

over the Wadi Dhuliel arid catchment

E. Abushandi and

B. Merkel

Title Page

Abstract

Introduction

Conclusions

Tables

References

Figures

14

$>$ I

4

Back

Close

Full Screen / Esc

Printer-friendly Version

Interactive Discussion 
and 2008, while Mafraq_60 meteorological station provides 1-hourly rainfall, temperature, and relative humidity records for the period between 2004 and 2006 . Unfortunately, some hourly records are missing from Mafraq_60 meteorological station. As observed from Mafraq_60 station, most of the rain events are related to low temperature 5 and high relative humidity (Fig. 8 and Table 3). Furthermore, a significant correlation between rainfall, temperature and relative humidity $(\mathrm{RH})$ was observed. The Spearman correlation coefficient (rho) between hourly temperature and rainfall rate is -0.28 (two tailed $P=0.48$ ), while Spearman's rho is 0.089 (two tailed $P=0.026$ ) between rainfall rate and $\mathrm{RH}$. Hourly wind speed records have also a positive correlation coeffio cient with rainfall records but not significant $(\rho=0.122$, two tailed $P=0.002)$. However, some anomalous satellite pixel values are detected and skipped from the adjustment process.

The next step towards adjustment is to aggregate 1-hourly dataset into daily, monthly, and annual datasets. For this the daily rainfall rates have been categorized into three groups: (i) Light $0.1-1.0 \mathrm{~mm} \mathrm{day}^{-1}$ (ii) Moderate 1.1-5.0 mm day ${ }^{-1}$, and (iii) Heavy $>5.0 \mathrm{~mm} \mathrm{day}^{-1}$. Zero values from both ground gauges and GSMaP_MVK+ were excluded. Consequently, GSMaP_MVK+ pixel estimates were compared to daily and monthly ground rain, temperature, wind speed, and relative humidity (Figs. 9 and 10). The comparison shows three groups:

1. GSMaP_MVK+ estimates matched the rain ground records rather fairly

2. GSMaP_MVK+ values are underestimates

\section{GSMaP_MVK+ values are overestimates}

In order to categorize monthly rain events into groups of similar trajectories K-means clustering was applied (Tables 3 and 4). The aim of this categorization was to assess the effect of external variables on rainfall rates to GSMaP_MVK estimates, air temperature, and wind speed records. The events with totals less than $2 \mathrm{~mm} \mathrm{month}^{-1}$ were excluded.
HESSD

$8,1665-1704,2011$

Rainfall estimation

over the Wadi Dhuliel arid catchment

E. Abushandi and

B. Merkel

Title Page

Abstract

Introduction

Conclusions

Tables

References

Figures

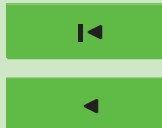

4

Back

Close

Full Screen / Esc

Printer-friendly Version

Interactive Discussion 
Multiple linear regressions (MLR) method was carried out to estimate convective and stratiform rain rates from GSMaP_MVK+ among temperature, relative humidity, and wind speed of daily and monthly records. The relationship between the ground rainfall records and the explanatory variables is represented for each station by the 5 following equations:

1. The MLR model for Mafraq_60 meteorological station daily records:

$$
\begin{aligned}
& \mathrm{Rf}_{\text {Light }}=\mathrm{GSMaP} \times 0.012-\text { Temp } \times 0.023+\mathrm{RH} \times 0.02+C_{1} \\
& \mathrm{Rf}_{\text {Moderate }}=\mathrm{GSMaP} \times 0.027-\mathrm{Temp} \times 0.068+\mathrm{RH} \times 0.01+C_{2} \\
& \mathrm{Rf}_{\text {Heavy }}=-\mathrm{GSMaP} \times 1.7+\mathrm{Temp} \times 1.03+\mathrm{RH} \times 0.99-C_{3}
\end{aligned}
$$

Where $\mathrm{Rf}_{\text {Light }}$ stands for the rainfall rate between $0.1-1.0 \mathrm{~mm}$ day $^{-1}, \mathrm{Rf}_{\text {Moderate }}$ is the rainfall between rate between $1.1-5.0 \mathrm{~mm}$ day $^{-1}, \mathrm{Rf}_{\text {Heavy }}$ is the rainfall rate more than $5.0 \mathrm{~mm}$ day $^{-1}$, GSMaP is the GSMaP_MVK+ estimates version 4.8.4 recorded in $\mathrm{mm}_{\text {day }}{ }^{-1}$, Temp is the temperature records in ${ }^{\circ} \mathrm{C}, \mathrm{RH}$ is the relative humidity in percentage, $C_{1}$ is the $\mathrm{Rf}_{\text {Light }}$ constant and equal to $0.164, C_{2}$ is the $\mathrm{Rf}_{\text {Moderate }}$ constant and equal to 4.46 , and $C_{3}$ is the $\mathrm{Rf}_{\text {Heavy }}$ constant and equal to 71.8 .

2. The MLR model for Um-Jimal meteorological station monthly records:

$$
\begin{aligned}
& \mathrm{Rf}_{\text {cluster1 }}=-\mathrm{GSMaP} \times 0.29-\text { Temp } \times 1.85+\mathrm{WS} \times 1.008+C_{\text {cluster1 }} \\
& \mathrm{Rf}_{\text {cluster2 }}=-\mathrm{GSMaP} \times 3.53+C_{\text {cluster2 }}
\end{aligned}
$$

Where $\mathrm{Rf}_{\text {cluster } 1}$ stands for the rainfall rate in $\mathrm{mm} \mathrm{month}^{-1}$ for the first group of cluster, $\mathrm{Rf}_{\text {cluster2 }}$ is the rainfall rate in $\mathrm{mm} \mathrm{month}^{-1}$ for the second cluster, and $C_{\text {cluster } 1}$ is the first cluster constant and equal to $38.8, C_{\text {cluster2 }}$ is the second cluster constant and equal to 78.42, and WS is wind speed in $\mathrm{km} \mathrm{h}^{-1}$.
HESSD

$8,1665-1704,2011$

Rainfall estimation

over the Wadi Dhuliel arid catchment

E. Abushandi and

B. Merkel

\section{Title Page}

Abstract

Introduction

Conclusions

References

Tables

Figures

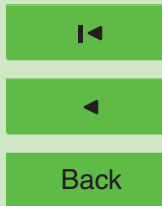

$>1$

$\checkmark$

Close

Full Screen / Esc

Printer-friendly Version

Interactive Discussion 
3. Monthly records of Es Samra meteorological station:

$$
\begin{aligned}
& \mathrm{Rf}_{\text {cluster1 }}=\mathrm{GSMaP} \times 1.03+\text { Temp } \times 1.86-\mathrm{WS} \times 5.13-C_{\text {cluster } 1} \\
& \mathrm{Rf}_{\text {cluster2 }}=-\mathrm{GSMaP} \times 0.64-\text { Temp } \times 2.77+\mathrm{WS} \times 5.12+C_{\text {cluster2 }}
\end{aligned}
$$

Where $C_{\text {cluster1 }}$ is equal to 44.2 and $C_{\text {cluster2 }}$ is equal to 56.1 .

Then, the MLR equations were chosen from all these combination to adjust GSMaP_MVK+ estimates:

$$
\text { GSMaP_MVK } \text { recalibrated }=\text { GSMaP_MVK } \text { original } \pm\left(G S M a P \_M V K_{\text {original }} \times R E\right)
$$

\section{Results}

Using the available weather records between 2003 and 2008 from nine meteorological and rain gauge stations over the Wadi Dhuliel complementary with GSMaP_MVK+ rainfall data showed a complex rainfall pattern in the Wadi Dhuliel.

The evaluation of daily and monthly GSMaP_MVK+ datasets exhibited good performance in capturing relative values of rainfall pattern but poor results with respect to estimating the absolute values of the rainfall. The comparison of daily and monthly GSMaP_MVK+ and ground records showed significant under- and overestimations in both spatial and temporal distributions. Separate from cases where GSMaP_MVK+ and ground records are correlated, in general GSMaP_MVK + records showed overestimation. Daily records of the GSMaP_MVK+ are showing $84 \%$ overestimation while in monthly records it is $59 \%$. Most of the annual rainfall magnitudes of GSMaP_MVK+ were overestimates (85.7\%); only the year 2003 exhibited correlation (Table 5).

In order to match GSMaP_MVK+ values in all cases within some acceptable error, an adjustment was performed based on ground data based on multiple linear

HESSD

$8,1665-1704,2011$

Rainfall estimation

over the Wadi Dhuliel arid catchment

E. Abushandi and

B. Merkel

Title Page

Abstract

Introduction

Conclusions

References

Tables

Figures

14

4

Back

Close

Full Screen / Esc

Printer-friendly Version

Interactive Discussion 
regressions. For daily time step, MLR equations were calculated for Mafraq 60 meteorological station and derived from temperature and relative humidity records as well as from GSMaP_MVK + daily estimates. Clustering rain events into light, moderate, and heavy storm helped to reduce the relative error. For monthly time step, explana5 tory variables used to develop MLR equations were calculated from two meteorological stations: Um-Jimal and Khirebit Es Samra. Here, the MLR equations derived from temperature and wind speed records as well as from GSMaP_MVK+ monthly estimates. Unfortunately monthly relative humidity is not available for these two stations. If the relationship between variables is not clear, clustering of monthly rainfall to 10 groups with respect to the variation of temperature, wind speed, and GSMaP_MVK+ estimates is a primary step to develop MLR models. The results of daily and monthly rainfall rates including under- and overestimates corresponding to each meteorological station after the calibration process are shown in Figs. 11 and 12 . The results showed good agreement between adjusted rainfall rates with ground station observations. The Spearman's correlation coefficient between adjusted and observed values for daily records shows significant correlation. The heavy storm events correlation coefficient was $-0.33(P=0.35)$, while for light and moderate storm events rho was -0.28 (two tailed $P=0.28$ ) and -0.32 (two tailed $P=0.37$ ), respectively. This may reflect the effect of extreme rain rates on Spearman's correlation coefficient.

Spatial rainfall analysis was based on Inverse Distance Weighting (IDW) interpolation method. Daily results included one meteorological station (Mafraq_60) and seven rain gauges. The MLR model was carried out for Mafraq_60 meteorological station and extended to the daily GSMaP_MVK+ pixel values (Eqs. 8 and 9). Adjusted daily GSMaP_MVK+ performed well in capturing the spatial patterns of the rainfall distribution, and showing more details especially on extreme rainfall events, while some weakness in light and moderate storms spatial distributions (Fig. 13).

The MLR model was computed for monthly records acquired from Khirebit Es Samra and Um-Jimal meteorological stations for the time between 2003 and 2008 . For ground interpolation, six other rain gauges were also used. The adjustment of GSMaP_MVK+

\section{HESSD}

$8,1665-1704,2011$

Rainfall estimation

over the Wadi Dhuliel arid catchment

E. Abushandi and

B. Merkel

Title Page

Abstract

Introduction

Conclusions

Tables

References

Figures

14

$\rightarrow$

4

Back

Close

Full Screen / Esc

Printer-friendly Version

Interactive Discussion

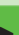

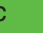

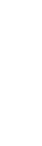


was primarily based on the average of Eqs. (8) and (9) calculated from both stations. The MLR model monthly rainfall estimates were found to be more reasonable than estimates obtained using daily MLR.

The evaluation of spatial patterns shows that monthly GSMaP_MVK+ does well in 5 capturing the topographic effect on precipitation distribution pattern, in particular for the west-east and north-south precipitation gradients (Fig. 14). A key outcome of the spatial and temporal analyses is the advantage of aggregating the fine scale data to coarser resolution (Fig. 15).

\section{Discussion}

10 Drawing conclusions from two disparate datasets may improve the quality of the combined data. Due to the sparseness of the rain gauge networks, interpolated data often are biased by the interpolation algorithms. In some cases, the ground rainfall gauges reveal slight homogeneity of rainfall magnitudes but the spatial distributions are, in general, heterogeneous. Furthermore, the number of stations and the length of historical records affect both spatial and temporal correlation structures. The results of this study are in agreement with previous works which showed that the characteristic of rainfall in arid catchment varies in space and time (Abu-Zreig et al., 2000; Lange et al., 2000; Pilgrim et al., 1988).

The results of (Dinku et al., 2010a,b; Iwasaki, 2009; Ushio et al., 2009) motivated us 20 to use the GSMaP_MVK+ in our study. Results of GSMaP_MVK+ were crosschecked against nine rain gauges observations assuming to represent reasonable and reliable point data. The compatibility between GSMaP_MVK+ and the ground rain gauges was limited to specific months. The over- or underestimation of the GSMaP_MVK+ in estimating rainfall in arid regions may be influenced by the following factors:

a. The sensors detected the rainfall aloft, meaning the rain may have evaporated before reaching the ground (Dinku et al., 2010a; Rosenfeld and Mintz, 1988).
HESSD

8, 1665-1704, 2011

Rainfall estimation

over the Wadi Dhuliel arid catchment

E. Abushandi and

B. Merkel

Title Page

Abstract

Introduction

Conclusions

Tables

References

Figures

14

4

Back

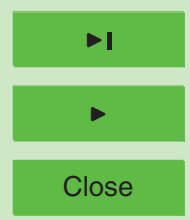

Full Screen / Esc

Printer-friendly Version

Interactive Discussion 
b. The moving vector Kalman filter algorithm was developed for precipitation over the tropical and sub-tropical regions (Iwasaki, 2009) using IR data as a means to move the precipitation estimates from microwave observation during periods when microwave data are not available. Obviously this estimate does not work always properly in arid areas.

c. The available GSMaP_MVK+ product was originally calibrated using ground based radar data located in tropical and sub-tropical regions of Japan, which may have different weather regime or covered by different cloud systems (Petty, 2001) than in arid regions.

d. An abrupt change in wind speed or wind direction below the cloud may have affected the rainfall area. A study conducted in Israel and Jordan by Sharon (1978) showed that the expansion of rainfall area may not be fully represented by point measurements. An increase of $10 \mathrm{~km} \mathrm{~h}^{-1}$ would constitute $12-15 \%$ of total rainfall.

e. The rainfall duration varied from storm to storm. The rainfall storm over the study area was characterized by high rainfall intensity (Fig. 16). This, however, might have occurred at the time when no satellite was overhead.

f. Desert dust and other aerosols may suppress rainfall and alter cloud microphysical properties (Han et al., 2008; Rosenfeld et al., 2001). The desert dust above and in the cloud could have distorted the satellite measurements (Rosenfeld et al., 2001). However, most of the previous related studies were usually based on homogenous water cloud models (Schutgens and Roebeling, 2009).

Precipitation in this area is very spotty in both time and space. The datasets in Fig. 16 were obtained from our station which was newly installed in the study area.

25 We are fully aware of the uncertainties associated with satellite derived rainfall maps and the original calibration from ground radar. Therefore an adjustment process for GSMaP_MVK + results was needed to achieve better match with ground observations 1678

\section{HESSD}

8, 1665-1704, 2011

Rainfall estimation

over the Wadi Dhuliel arid catchment

E. Abushandi and

B. Merkel

Title Page

Abstract

Introduction

Conclusions

Tables

References

Figures

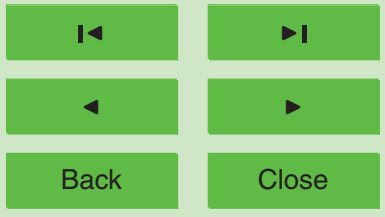

Full Screen / Esc

Printer-friendly Version

Interactive Discussion 
in arid regions. Multiple linear regression analysis proved to be an appropriate technique using additional weather data. As expected, rainfall events showed higher intensities in the western parts, while eastern parts are characterized by lower rainfall rates. In some cases the rainfall distribution did not show the west-east gradient. This may 5 be related to climatic and topographic variations. The high-resolution GSMaP_MVK+ dataset allowed us to evaluate and estimate the amount of rainfall in regions where no ground rainfall stations were available. Thus, the gridding interpolation method provided a qualitative view of the rainfall distribution. However, it is important to note that the interpolation technique explicitly derived new spatial values based on the number 10 of present rain gauges, and, if the number of the gauges is limited, the unknown points may not be interpolated properly.

Allowance for other weather variables such as radiation, evaporation, and would improve the accuracy of Global Satellite Mapping of Precipitation estimates. Furthermore, employing other satellite and aircraft observation for retrieving clouds properties may enhance our understanding of the microphysical impact of aerosols on water clouds. However, the quality of this rainfall analysis will be affected by paucity of data in the region.

\section{Conclusions}

The climate in the Wadi Dhuliel area is characterized by high rainfall variability. Hence, 20 it is difficult to estimate the spatial rainfall variability by a simple gridding method. Rainfall records from different rain gauges showed a complex rainfall regime in the area. Rainfall distribution in the Wadi Dhuliel varies with location mainly due to topographic variations as one move from semi-arid to arid regions. A Global Satellite Mapping of Precipitation dataset, currently known as GSMaP_MVK+ Version 4.8.4, was compared GSMaP_MVK + over arid catchments is limited. Overall, GSMaP_MVK+ showed the best performance in comparison with other satellite products. The results showed how

HESSD

$8,1665-1704,2011$

Rainfall estimation

over the Wadi Dhuliel arid catchment

E. Abushandi and

B. Merkel

Title Page

Abstract

Introduction

Conclusions

Tables

References

Figures

14

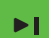

4

Back

Close

Full Screen / Esc

Printer-friendly Version

Interactive Discussion

1679 
topographic variation can influence the rainfall distribution, especially in the northern part of the catchment. Higher rainfall rates in the western parts and the lower rainfall rates in eastern parts may explain the change in climate from arid area to desert area. Moreover, aggregating hourly rain rate into coarser time step, daily and monthly, will 5 contribute to more accurate rain estimation.

Acknowledgement. The authors are thankful to Jordan Ministry of Water and Irrigation, particularly the Surface Water Unit, and the Jordan Meteorological Department for providing the necessary datasets. Special thanks go to all members of the GSMaP project for providing the GSMaP dataset.

Abdulla, F. and Al-Assa'd, T.: Modeling of groundwater flow for Mujib aquifer, Jordan, J. Earth Syst. Sci., 115, 289-297, 2006.

Abu-Zreig, M., Attom, M., and Hamasha, N.: Rainfall harvesting using sand ditches in Jordan, Agr. Water Manage., 46, 183-192, 2000.

AbuAwwad, A. M. and Shatanawi, M. R.: Water harvesting and infiltration in arid areas affected by surface crust: examples from Jordan, J. Arid Environ., 37, 443-452, 1997.

Adler, R. F., Huffman, G. J., Bolvin, D. T., Curtis, S., and Nelkin, E. J.: Tropical rainfall distributions determined using TRMM combined with other satellite and rain gauge information, J. Appl. Meteorol., 39, 2007-2023, 2000.

20 Akhtari, R., Morid, S., Mahdian, M. H., and Smakhtin, V.: Assessment of areal interpolation methods for spatial analysis of SPI and EDI drought indices, Int. J. Climatol., 29, 135-145, 2009.

Beven, K.: On fire and rain (or predicting the effects of change), Hydrol. Process., 15, 13971399, 2001.

Brezonik, P. L. and Stadelmann, T. H.: Analysis and predictive models of stormwater runoff volumes, loads, and pollutant concentrations from watersheds in the Twin Cities metropolitan area, Minnesota, USA, Water Res., 36, 1743-1757, 2002.
HESSD

$8,1665-1704,2011$

Rainfall estimation

over the Wadi Dhuliel arid catchment

E. Abushandi and

B. Merkel

Title Page

Abstract

Introduction

Conclusions

References

Tables

Figures

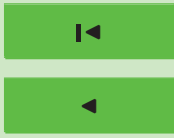

- I

Back

Close

Full Screen / Esc

Printer-friendly Version

Interactive Discussion 
Croke, B. F. W. and Jakeman, A. J.: Use of the IHACRES rainfall-runoff model in arid and semi arid regions, in: Hydrological Modelling in Arid and Semi-Arid Areas, edited by: Wheater, $\mathrm{H}$., Sorooshian, S., and Sharma, K. D., Cambridge University Press, Cambridge, 41-48, 2007.

Dinku, T., Ceccato, P., Cressman, K., and Connor, S. J.: Evaluating detection skills of satellite rainfall estimates over desert locust recession regions, J. Appl. Meteorol. Clim., 49, 13221332, 2010a.

Dinku, T., Ruiz, F., Connor, S. J., and Ceccato, P.: Validation and intercomparison of satellite rainfall estimates over Colombia, J. Appl. Meteorol. Clim., 49, 1004-1014, 2010b.

Dolman, A. J. and Gregory, D.: The parametrization of rainfall interception in GCMs - Reply, Q. J. Roy. Meteor. Soc., 120, 735-736, 1994.

Freiwan, M. and Kadioglu, M.: Spatial and temporal analysis of climatological data in Jordan, Int. J. Climatol., 28, 521-535, 2008.

Gajiccapka, M.: Periodicity of annual precipitation in different climate regions of Croatia, Theor. Appl. Climatol., 49, 213-216, 1994.

15 Goldreich, Y.: Temporal variations of rainfall in Israel, Climate Res., 5, 167-179, 1995.

Han, Y., Dai, X., Fang, X., Chen, Y., and Kang, F.: Dust aerosols: A possible accelerant for an increasingly arid climate in North China, J. Arid Environ., 72, 1476-1489, 2008.

Huffman, G. J., Adler, R. F., Morrissey, M. M., Bolvin, D. T., Curtis, S., Joyce, R., McGavock, B., and Susskind, J.: Global precipitation at one-degree daily resolution from multisatellite observations, J. Hydrometeorol., 2, 36-50, 2001.

Huffman, G. J., Adler, R. F., Bolvin, D. T., Gu, G. J., Nelkin, E. J., Bowman, K. P., Hong, Y., Stocker, E. F., and Wolff, D. B.: The TRMM multisatellite precipitation analysis (TMPA): quasiglobal, multiyear, combined-sensor precipitation estimates at fine scales, J. Hydrometeorol., 8, 38-55, 2007.

Iwasaki, H.: NDVI prediction over Mongolian grassland using GSMaP precipitation data and JRA-25/JCDAS temperature data, J. Arid Environ., 73, 557-562, 2009.

Lange, J., Liebundgut, C., and Schick, A. P.: The importance of single events in arid zone rainfall-runoff modelling, Phys. Chem. Earth Pt. B, 25, 673-677, 2000.

Manik, T. and Sidle, R.: Rainfall Spatial Distribution in Sumber Jaya Watershed, Lampung, Indonesia, 2003.

Merkel, B. and Sperling, B.: Raster based modelling of watersheds and flow accumulation, in: Application of Geographic Information Systems in Hydrology and Water Resources Management, edited by: Kovar, K. and Nachtnebel, H. P., IAHS Publication No. 211, 193-199,
HESSD

8, 1665-1704, 2011

\section{Rainfall estimation \\ over the Wadi Dhuliel arid catchment \\ E. Abushandi and \\ B. Merkel}

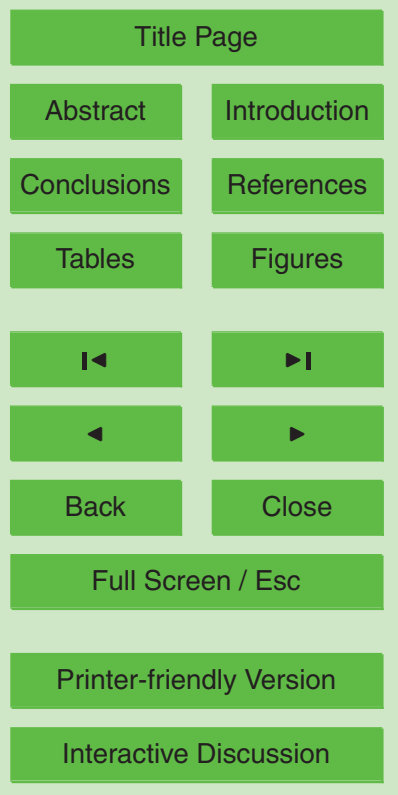


1993.

Momani, N.: Time series analysis model for rainfall data in Jordan: case study for using time series analysis, Am. J. Environ. Sci., 5, 599-604, 2009.

Oweis, T. Y. and Taimeh, A. Y.: Evaluation of a small basin water-harvesting system in the Arid region of Jordan, Water Resour. Manage., 10, 21-34, 1995.

Pal, I. and Al-Tabbaa, A.: Trends in seasonal precipitation extremes - an indicator of "climate change" in Kerala, India, J. Hydrol., 367, 62-69, 2009.

Petty, G. W.: Physical and microwave radiative properties of precipitating clouds, Part II: A parametric 1D rain-cloud model for use in microwave radiative transfer simulations, J. Appl. Me10 teorol., 40, 2115-2129, 2001.

Pilgrim, D. H., Chapman, T. G., and Doran, D. G.: Problems of rainfall-runoff modeling in arid and semiarid regions, Hydrolog. Sci. J., 33, 379-400, 1988.

Rosenfeld, D. and Mintz, Y.: Evaporation of rain falling from convective clouds as derived from radar measurements, J. Appl. Meteorol., 27, 209-215, 1988.

15 Rosenfeld, D., Rudich, Y., and Lahav, R.: Desert dust suppressing precipitation: A possible desertification feedback loop, P. Natl. Acad. Sci. USA, 98, 5975-5980, 2001.

Schutgens, N. A. J. and Roebeling, R. A.: Validating the validation: the influence of liquid water distribution in clouds on the intercomparison of satellite and surface observations, J. Atmos. Ocean. Tech., 26, 1457-1474, 2009.

20 Sorooshian, S., Hsu, K. L., Gao, X., Gupta, H. V., Imam, B., and Braithwaite, D.: Evaluation of PERSIANN system satellite-based estimates of tropical rainfall, B. Am. Meteorol. Soc., 81, 2035-2046, 2000.

Tarawneh, Q. and Kadioglu, M.: An analysis of precipitation climatology in Jordan, Theor. Appl. Climatol., 74, 123-136, 2003.

25 Thiessen, A. H.: Precipitation averages for large areas, Mon. Weather Rev., 39(7), 1082-1084, 1911.

Tian, Y. D., Peters-Lidard, C. D., Adler, R. F., Kubota, T., and Ushio, T.: Evaluation of GSMaP precipitation estimates over the contiguous United States, J. Hydrometeorol., 11, 566-574, 2010.

so Ushio, T., Sasashige, K., Kubota, T., Shige, S., Okamoto, K., Aonashi, K., Inoue, T., Takahashi, N., Iguchi, T., Kachi, M., Oki, R., Morimoto, T., and Kawasaki, Z. I.: A Kalman filter approach to the global satellite mapping of precipitation (GSMaP) from combined passive microwave and infrared radiometric data, J. Meteorol. Soc. Jpn., 87, 137-151, 2009.

HESSD

$8,1665-1704,2011$

\section{Rainfall estimation \\ over the Wadi Dhuliel arid catchment \\ E. Abushandi and \\ B. Merkel}

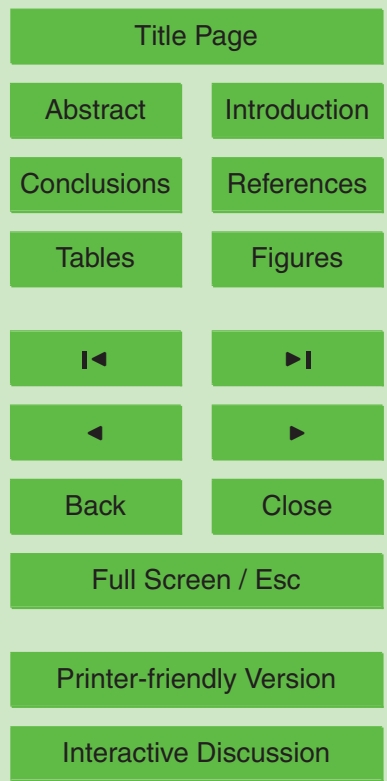


Vieux, B. E. and Vieux, J. E.: Statistical evaluation of a radar rainfall system for sewer system management, Atmos. Res., 77, 322-336, 2005.

Wong, G., Lambert, M. F., Leonard, M., and Metcalfe, A. V.: Drought analysis using trivariate copulas conditional on climatic states, J. Hydrol. Eng., 15, 129-141, 2010.

5 Xie, P. P., Janowiak, J. E., Arkin, P. A., Adler, R., Gruber, A., Ferraro, R., Huffman, G. J., and Curtis, S.: GPCP Pentad precipitation analyses: an experimental dataset based on gauge observations and satellite estimates, J. Climate, 16, 2197-2214, 2003.

\section{HESSD}

$8,1665-1704,2011$

\section{Rainfall estimation over the Wadi Dhuliel arid catchment \\ E. Abushandi and \\ B. Merkel}

Title Page

Abstract

Conclusions

Tables

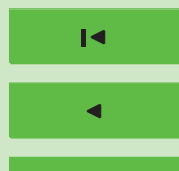

Back
Introduction

References

Figures

$\rightarrow$ I

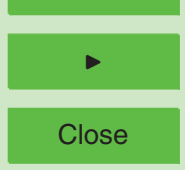

Full Screen / Esc

Printer-friendly Version 


\section{HESSD}

8, 1665-1704, 2011

Table 1. Input datasets to produce GSMaP_MVK+ from four different types of satellite sensors.

\begin{tabular}{|c|c|c|c|}
\hline Input data & Sensor & $\begin{array}{l}\text { GSMaP near- } \\
\text { realtime system }\end{array}$ & $\begin{array}{l}\text { GSMaP standard } \\
\text { system }\end{array}$ \\
\hline \multirow[t]{2}{*}{$\begin{array}{l}\text { Passive } \\
\text { microwave } \\
\text { radiometer }\end{array}$} & $\begin{array}{l}\text { TRMM/The Tropical } \\
\text { Rainfall Measuring } \\
\text { Mission (TMI) }\end{array}$ & $\begin{array}{l}\text { NASA/GSFC } \\
\text { Real-time version }\end{array}$ & $\begin{array}{l}\text { NASA/GSFC } \\
\text { Standard } \\
\text { version }\end{array}$ \\
\hline & $\begin{array}{l}\text { Aqua/AMSR-E } \\
\text { DMSP/SSMI (F13, } \\
14,15)\end{array}$ & $\begin{array}{l}\text { JAXA/EORC } \\
\text { NOAA/NWS }\end{array}$ & $\begin{array}{l}\text { JAXA/EORC } \\
\text { Remote sensing } \\
\text { systems }\end{array}$ \\
\hline $\begin{array}{l}\text { GEO infrared } \\
\text { radiometer }\end{array}$ & $\begin{array}{l}\text { MTSAT, METEOSAT- } \\
7 / 8, \text { GOES-11/12 }\end{array}$ & $\begin{array}{l}\text { Globally-merged } \\
\text { pixel-resolution } \\
\text { data by JWA }\end{array}$ & $\begin{array}{l}\text { Globally-merged } \\
\text { pixel-resolution data } \\
\text { by GSFC/DAAC }\end{array}$ \\
\hline $\begin{array}{l}\text { Atmospheric } \\
\text { information }\end{array}$ & - & $\begin{array}{l}\text { JMA Global Analysis } \\
\text { (GANAL) Real-time } \\
\text { version }\end{array}$ & $\begin{array}{l}\text { JMA Global Analysis } \\
\text { (GANAL) }\end{array}$ \\
\hline $\begin{array}{l}\text { Sea surface } \\
\text { temperature }\end{array}$ & - & JMA MGDSST & JMA MGDSST \\
\hline
\end{tabular}

\section{Rainfall estimation over the Wadi Dhuliel arid catchment \\ E. Abushandi and \\ B. Merkel}

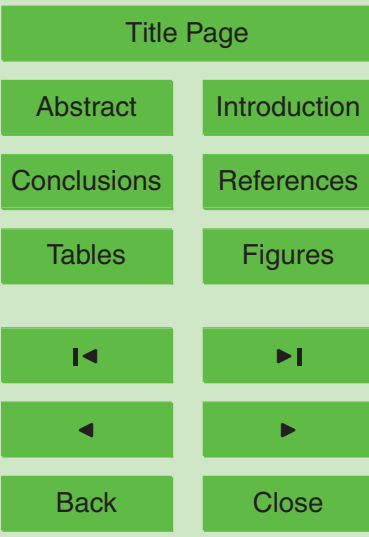

Full Screen / Esc

Printer-friendly Version

Interactive Discussion 
Table 2. Information about meteorological and rain gauging stations utilized for the study.

HESSD

8, 1665-1704, 2011

\begin{tabular}{|c|c|c|c|c|c|}
\hline $\begin{array}{l}\text { Station code } \\
\text { on the map } \\
\text { (Figs. } 3 \text { and } 7 \text { ) }\end{array}$ & $\begin{array}{l}\text { Station } \\
\text { code } \\
\text { (JMWI) }\end{array}$ & Station name & $\begin{array}{l}\text { Altitude } \\
\text { (a.m.s.l. } \\
\text { in } \mathrm{m} \text { ) }\end{array}$ & $\begin{array}{l}\text { Data } \\
\text { type }\end{array}$ & $\begin{array}{l}\text { Mean annual } \\
\text { rainfall }(\mathrm{mm})\end{array}$ \\
\hline A & AL0058 & $\begin{array}{l}\text { Sabha and } \\
\text { Subhiyeh }\end{array}$ & 843 & $\begin{array}{l}\text { Monthly } \\
\text { and daily }\end{array}$ & 109.3 \\
\hline B & AL0059 & Um-Jimal ${ }^{*}$ & 670 & $\begin{array}{l}\text { Monthly } \\
\text { and daily }\end{array}$ & 110 \\
\hline C & AL0048 & Al-Khaldiya & 600 & $\begin{array}{l}\text { Monthly } \\
\text { and daily }\end{array}$ & 123.9 \\
\hline $\mathrm{D}$ & AL0055 & $\begin{array}{l}\text { Wadi Dhuliel } \\
\text { Nursery }\end{array}$ & 580 & $\begin{array}{l}\text { Monthly } \\
\text { and daily }\end{array}$ & 130.3 \\
\hline$E$ & AL0049 & $\begin{array}{l}\text { Qasr Al- } \\
\text { hallabat }\end{array}$ & 590 & $\begin{array}{l}\text { Monthly } \\
\text { and daily }\end{array}$ & 72.4 \\
\hline $\mathrm{F}$ & AL0054 & Hashimiya & 566 & $\begin{array}{l}\text { Monthly } \\
\text { and daily }\end{array}$ & 135.3 \\
\hline G & AL0066 & $\begin{array}{l}\text { Khirebit Es } \\
\text { Samra Evap. St. }\end{array}$ & 564 & $\begin{array}{l}\text { Monthly } \\
\text { and daily }\end{array}$ & 131.9 \\
\hline $\mathrm{H}$ & No code & Almfraq & 675 & Monthly & 158 \\
\hline I & No code & Mafraq_60* & 675 & Hourly & 143 \\
\hline
\end{tabular}

\section{Rainfall estimation} over the Wadi Dhuliel arid catchment

E. Abushandi and

B. Merkel

\section{Title Page}

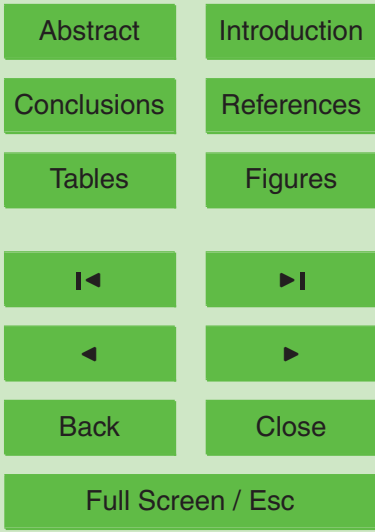

Printer-friendly Version

* Meteorological station.

Interactive Discussion 


\section{HESSD}

8, 1665-1704, 2011

\section{Rainfall estimation over the Wadi Dhuliel arid catchment \\ E. Abushandi and \\ B. Merkel}

Table 3. K-means cluster analysis of monthly air temperature, wind speed, and GSMaP_MVK+ for Um-Jimal metrological station (2003-2008).

\begin{tabular}{lrrrr}
\hline Variable & $\begin{array}{r}\text { Cluster } \\
\text { No } 1^{*}\end{array}$ & $\begin{array}{r}\text { Cluster } \\
\text { No 2** }\end{array}$ & $\begin{array}{r}\text { Std. deviation } \\
\text { (cluster 1) }\end{array}$ & $\begin{array}{r}\text { Std. deviation } \\
\text { (cluster 2) }\end{array}$ \\
\hline Average temperature $\left({ }^{\circ} \mathrm{C}\right)$ & 11.3 & 10.0 & 3.56 & 6.4 \\
Wind speed $\left(\mathrm{km} \mathrm{h}^{-1}\right)$ & 9.3 & 25.54 & 5.54 & 1.6 \\
GSMaP_MVK+ $\left(\mathrm{mm} \mathrm{month}^{-1}\right)$ & 23.3 & 105.9 & 16.6 & 48.8 \\
\hline
\end{tabular}

* The number of cases in cluster number 1 is 22 .

** The number of cases in cluster number 2 is 2 .

Title Page

Abstract

Introduction

Conclusions

References

Tables

Figures

14

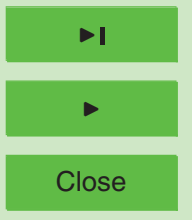

Back

Full Screen / Esc

Printer-friendly Version

Interactive Discussion 


\section{HESSD}

$8,1665-1704,2011$

\section{Rainfall estimation over the Wadi Dhuliel arid catchment \\ E. Abushandi and \\ B. Merkel}

Table 4. K-means cluster analysis of monthly air temperature, wind speed, and GSMaP_MVK+ Khirebit Es Samra metrological station (2003-2008).

\begin{tabular}{lrrrr}
\hline Variable & $\begin{array}{r}\text { Cluster } \\
\text { No } 1^{*}\end{array}$ & $\begin{array}{r}\text { Cluster } \\
\text { No 2* }\end{array}$ & $\begin{array}{r}\text { Std. deviation } \\
\text { (cluster 1) }\end{array}$ & $\begin{array}{r}\text { Std. deviation } \\
\text { (cluster 2) }\end{array}$ \\
\hline Average temperature $\left({ }^{\circ} \mathrm{C}\right)$ & 10.77 & 13.3 & 3.52 & 2.87 \\
Wind speed $\left(\mathrm{km} \mathrm{h}^{-1}\right)$ & 2.5 & 2.7 & 1.17 & 0.9 \\
GSMaP_MVK+ $\left(\mathrm{mm} \mathrm{month}^{-1}\right)$ & 86.45 & 15.6 & 12.92 & 20.1 \\
\hline
\end{tabular}

* The number of cases in cluster number 1 is 6 .

** The number of cases in cluster number 2 is 19.

Title Page

Abstract

Introduction

Conclusions

References

Tables

Figures

14

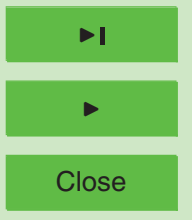

Back

Full Screen / Esc

Printer-friendly Version

Interactive Discussion 
Table 5. Annual rainfall of GSMaP_MVK+ compared to 8 ground rain gauge stations.

HESSD

\begin{tabular}{llrrrr}
\hline Data type & Date & Hashimiya & $\begin{array}{r}\text { Khirebit } \\
\text { Es-Samra }\end{array}$ & $\begin{array}{r}\text { W. Dhuliel } \\
\text { Nursery }\end{array}$ & $\begin{array}{r}\text { Um El- } \\
\text { Jumal }\end{array}$ \\
\hline GSMaP & 2003 & 114.02 & 136.44 & 125.71 & 162.08 \\
Ground record & & 184.2 & 194 & 138.9 & 172.8 \\
GSMaP & 2004 & 365.44 & 400.99 & 396.99 & 597.43 \\
G Record & & 114.6 & 130 & 85.4 & 74.2 \\
GSMaP & 2005 & 232.68 & 256.72 & 231.26 & 455.99 \\
Ground records & & 122.9 & 124 & 86.2 & 105 \\
GSMaP & 2006 & 321.61 & 334.07 & 308.5 & 367.56 \\
Ground records & & 102.8 & 86.8 & 97.5 & 79.2 \\
GSMaP & Dec 2007* & 10.04 & 10.4 & 9.65 & 21.58 \\
Ground records & & 14 & 12.6 & 8.5 & 23 \\
GSMaP & 2008 & 112.35 & 109.03 & 123.22 & 181.09 \\
Ground records & & 77.7 & 77 & 46.8 & 83 \\
\hline Data type & Date & Khaldiya & Sabha and & Qasr El- & $\mathrm{Al}$ \\
& & & Subhiyeh & Hallabat & Mafraq \\
\hline GSMaP & 2003 & 127.37 & 161.7 & 80.43 & 162.95 \\
Ground Record & & 143.9 & 146.9 & 40.8 & 54.6 \\
GSMaP & 2004 & 374.49 & 567.42 & 295.48 & 385.96 \\
G Record & & 91.5 & 86.7 & 74.7 & 105.7 \\
GSMaP & 2005 & 248.58 & 412.07 & 153.67 & 466.42 \\
Ground records & & 100.7 & 97.1 & 69.7 & 123.7 \\
GSMaP & 2006 & 309.86 & 361.51 & 311.34 & 396.41 \\
Ground records & & 99.3 & 96.8 & 47 & $\mathrm{NA}$ \\
GSMaP & Dec 2007 & 11.46 & 20.8 & 10.24 & 20.5 \\
Ground records & & 8.5 & 16.5 & 6 & $\mathrm{NA}$ \\
GSMaP & $2008^{* *}$ & 124.68 & 164.18 & 120.67 & 122.7 \\
Ground records & & 62 & 105.1 & 30.4 & $\mathrm{NA}$ \\
\hline
\end{tabular}

* The available month from 2007 is December only.

** Jan, Feb, and Mar in 2008 have no error estimates.
8, 1665-1704, 2011

\section{Rainfall estimation over the Wadi Dhuliel arid catchment}

E. Abushandi and

B. Merkel

\section{Title Page}

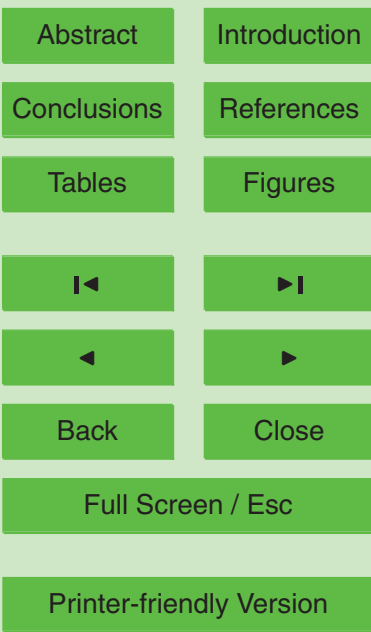

Interactive Discussion 


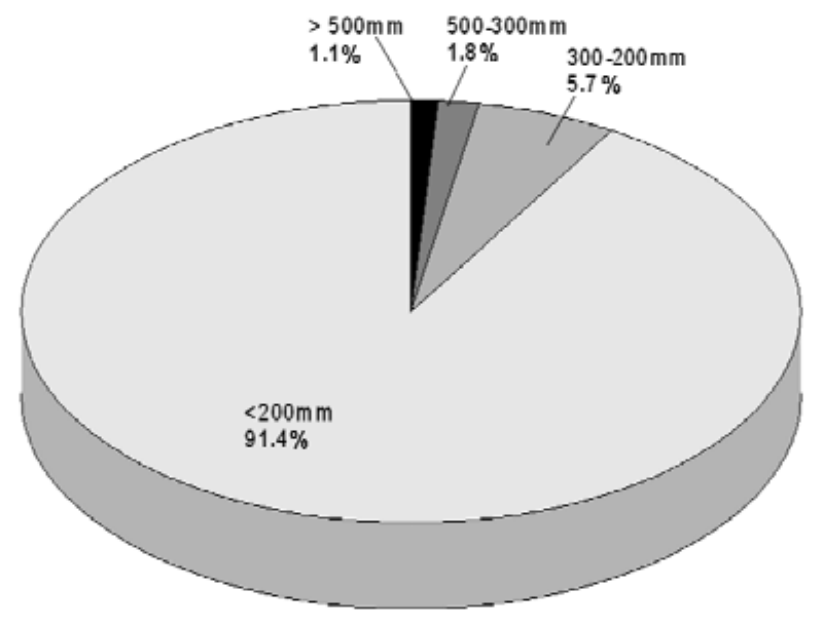

\section{HESSD}

8, 1665-1704, 2011

\section{Rainfall estimation over the Wadi Dhuliel arid catchment \\ E. Abushandi and \\ B. Merkel}

Fig. 1. Rainfall distribution in Jordan (JMWI).

Printer-friendly Version

Interactive Discussion

Abstract

Conclusions

Tables

14

4

Back

Full Screen / Esc 
HESSD

$8,1665-1704,2011$

\section{Rainfall estimation over the Wadi Dhuliel arid catchment \\ E. Abushandi and \\ B. Merkel}

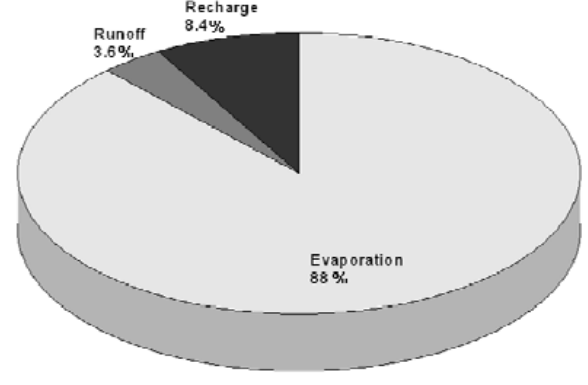

A

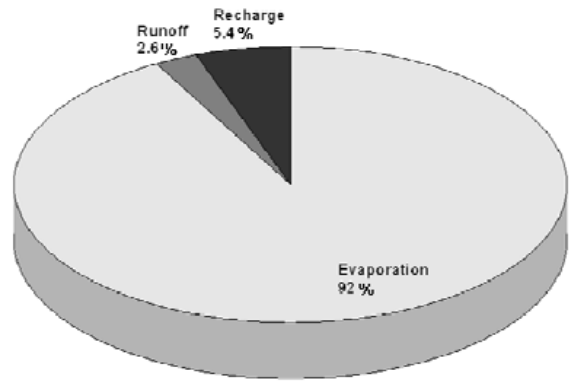

B
Fig. 2. The percentages of hydrologic water balance for Jordan (A) and particularly the Wadi Dhuliel in Northeast Jordan (B) (JMWI).

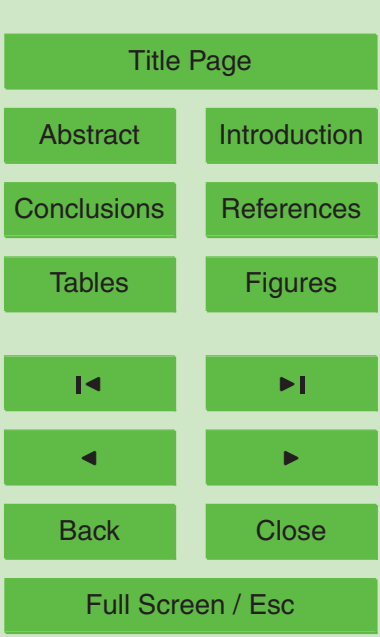

Printer-friendly Version

Interactive Discussion 
HESSD

8, 1665-1704, 2011

\section{Rainfall estimation over the Wadi Dhuliel arid catchment \\ E. Abushandi and \\ B. Merkel}

\section{Title Page}

\section{Abstract}

Conclusions

A Rain Gauge

- Meteorological station $\underset{x}{x}$ GSMaP

40 Kilometers

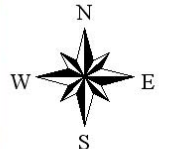

Fig. 3. Study area and the rain gauges locations Location map of Al-Zarqa basin including the sub-basins Seil Al-Zarqa and Wadi Dhuliel.
$\mathbb{N}$

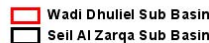

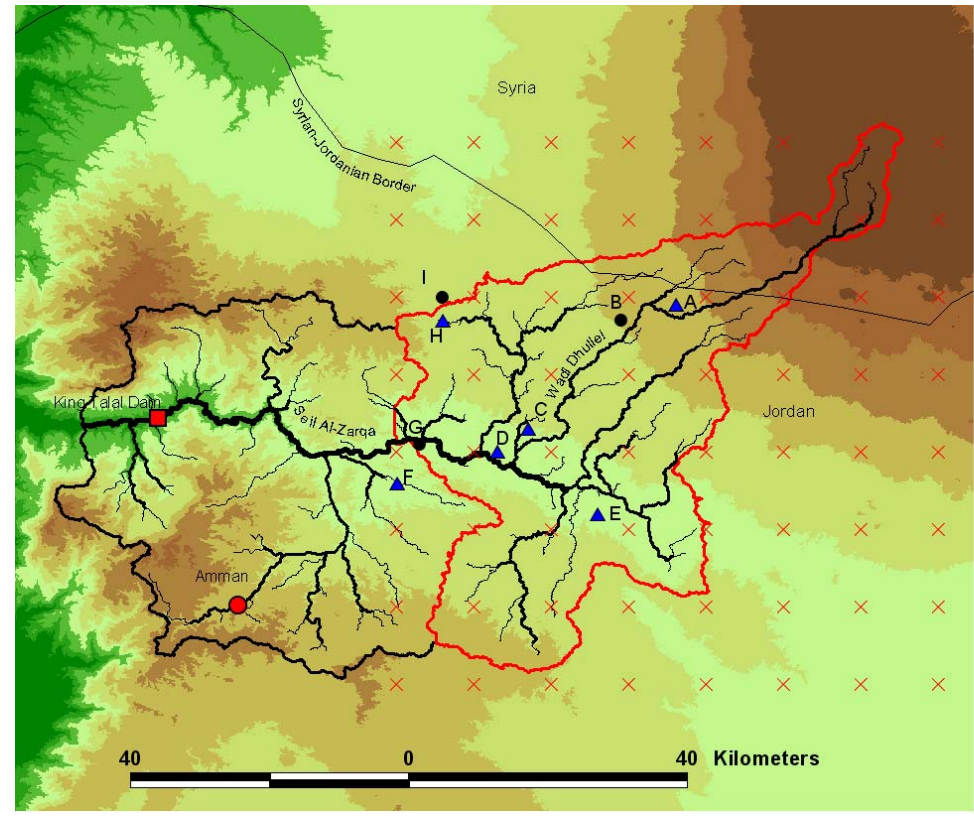

Tables

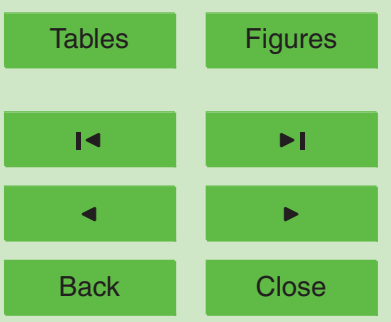

Full Screen / Esc

Printer-friendly Version

Interactive Discussion 


\section{HESSD}

8, 1665-1704, 2011

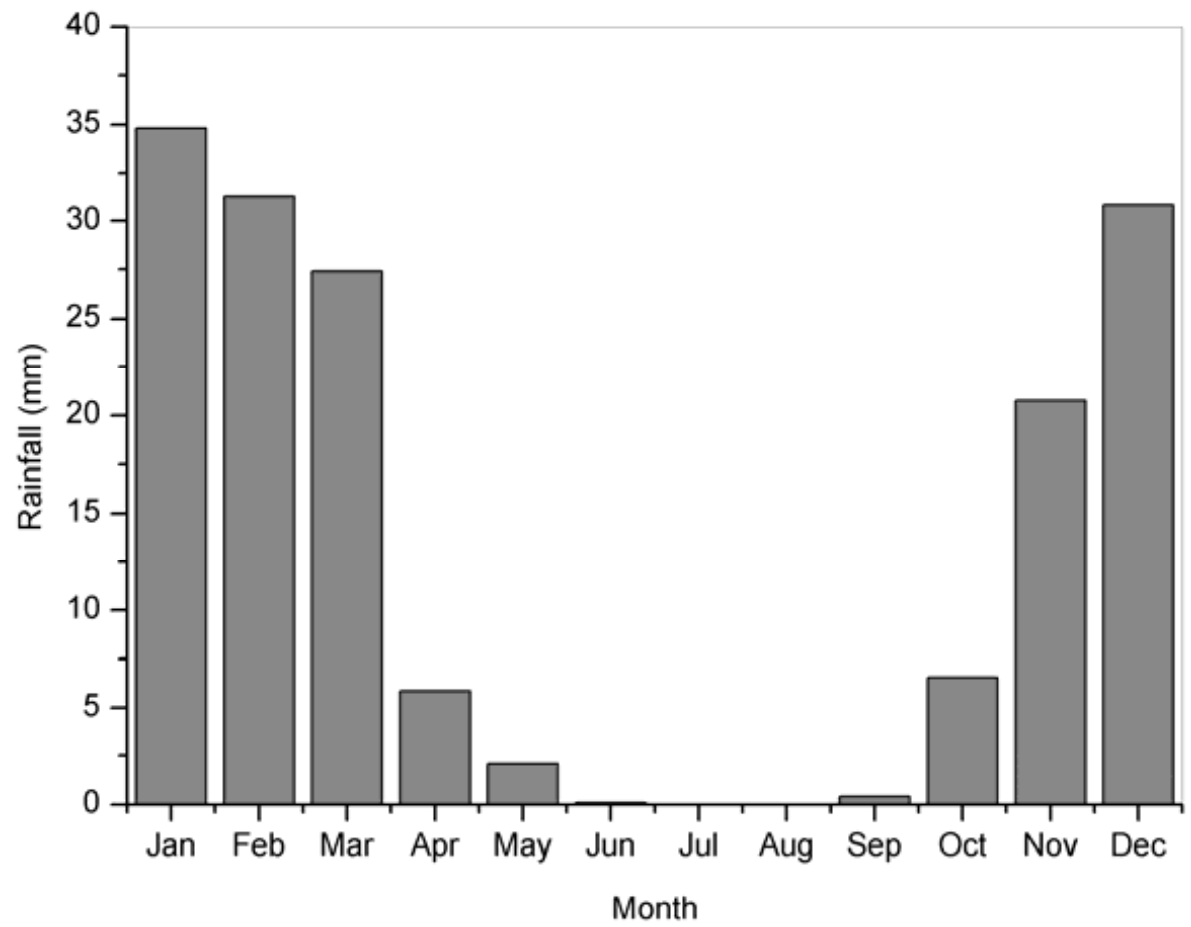

\section{Rainfall estimation over the Wadi Dhuliel arid catchment \\ E. Abushandi and \\ B. Merkel}

Title Page

Abstract

Introduction

Conclusions

References

Tables

Figures

14

4

Back

Full Screen / Esc

Printer-friendly Version

Interactive Discussion 


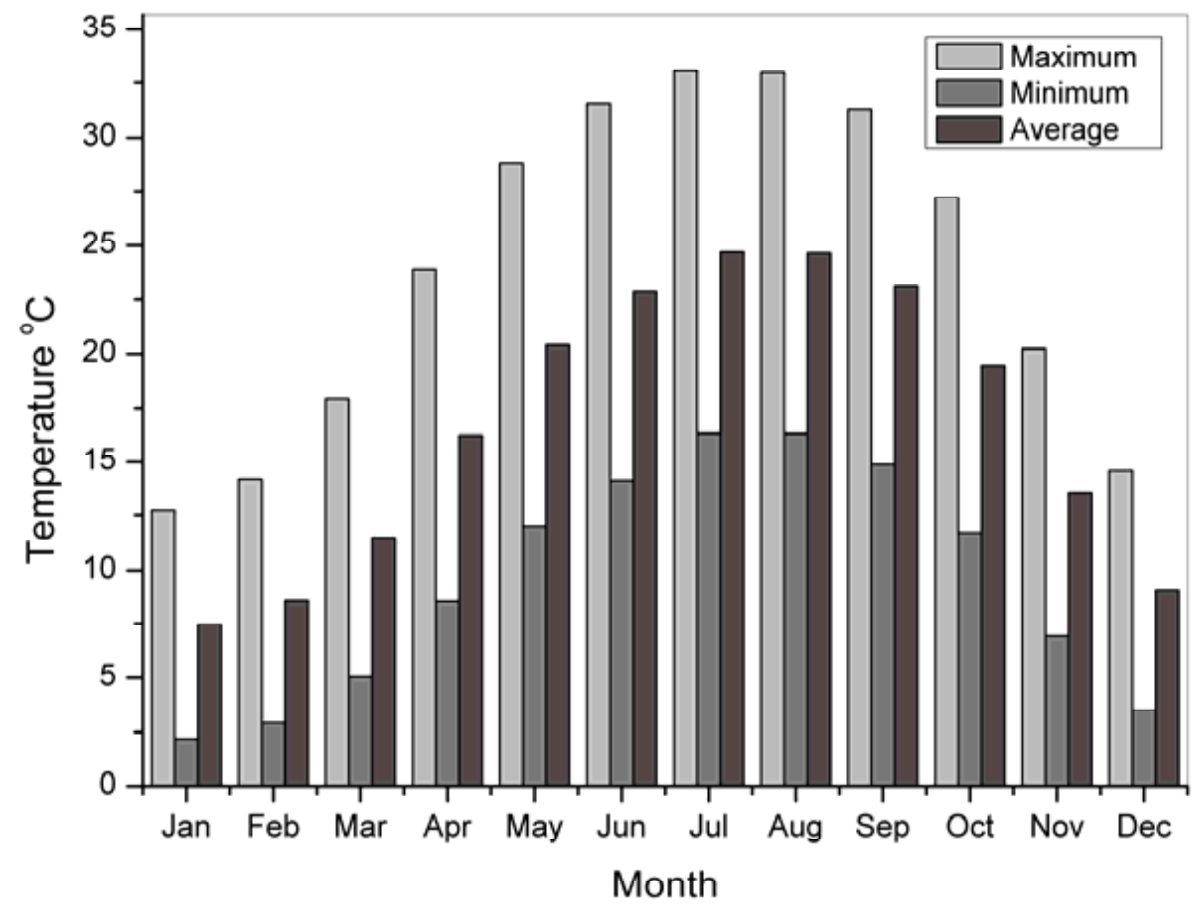

HESSD

8, 1665-1704, 2011

\section{Rainfall estimation over the Wadi Dhuliel arid catchment \\ E. Abushandi and \\ B. Merkel}

Title Page

Abstract

Conclusions

Tables

14

4

Back

Full Screen / Esc

Printer-friendly Version

Interactive Discussion 


\section{HESSD}

8, 1665-1704, 2011

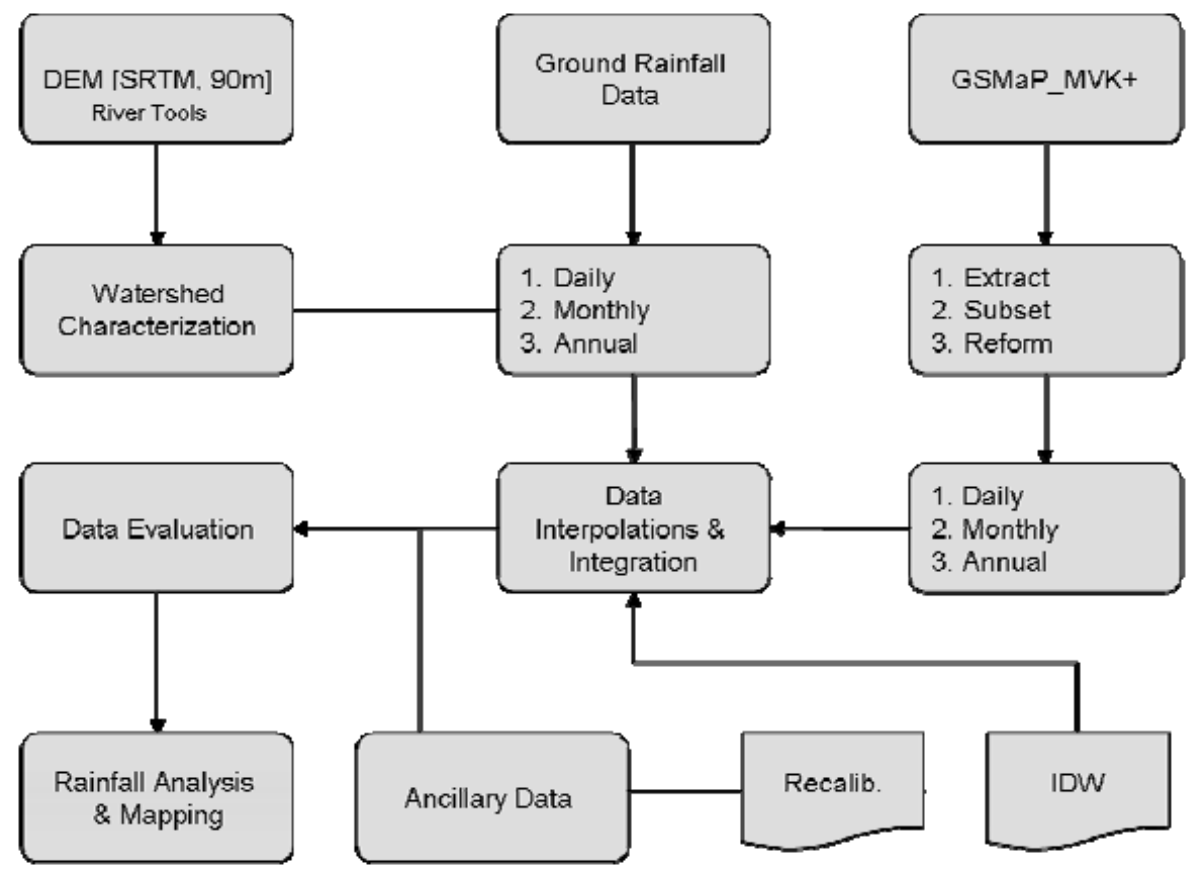

\section{Rainfall estimation over the Wadi Dhuliel arid catchment \\ E. Abushandi and \\ B. Merkel}

\section{Title Page}

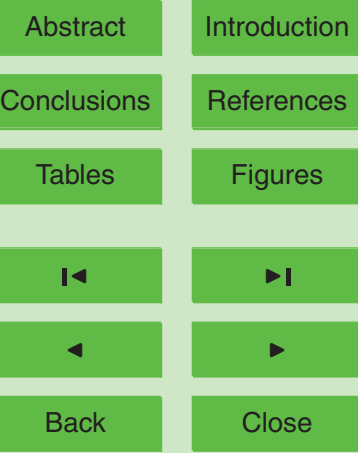

Full Screen / Esc

Fig. 6. Research process flowchart. 


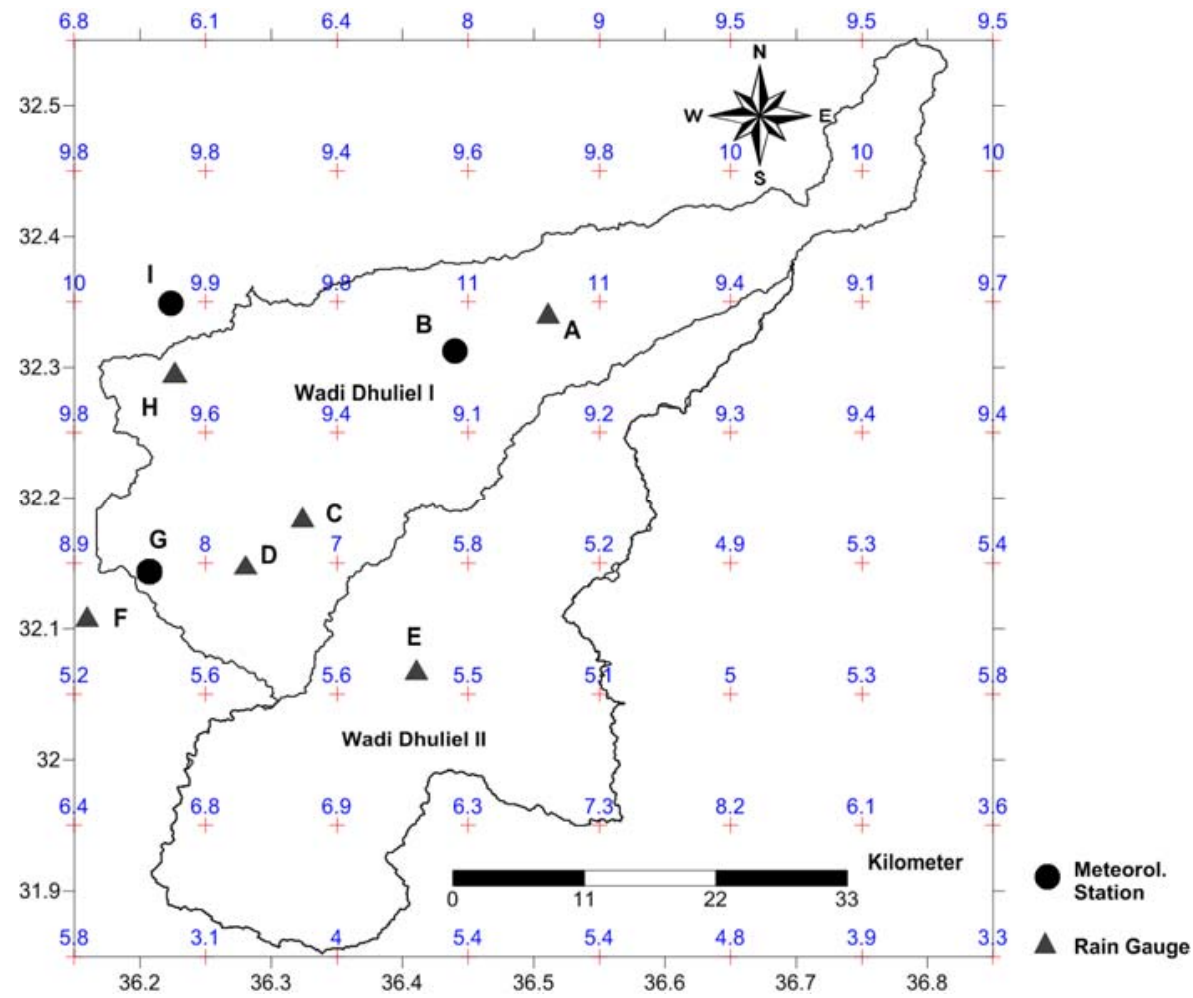

HESSD

8, 1665-1704, 2011

Rainfall estimation over the Wadi Dhuliel arid catchment

E. Abushandi and

B. Merkel

\section{Title Page}

\section{Abstract}

Introduction

Conclusions

References

Tables

Figures

14

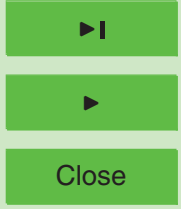

Back

Full Screen / Esc

Fig. 7. The GSMaP_MVK + pixels distribution around and over Wadi Dhuliel catchment (Rainfall mm month ${ }^{-1}$, January 2003).

Printer-friendly Version

Interactive Discussion 


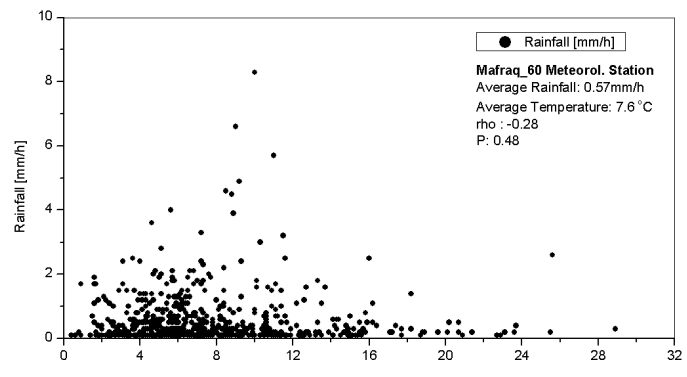

\section{HESSD}

8, 1665-1704, 2011

\section{Rainfall estimation over the Wadi Dhuliel arid catchment \\ E. Abushandi and \\ B. Merkel}

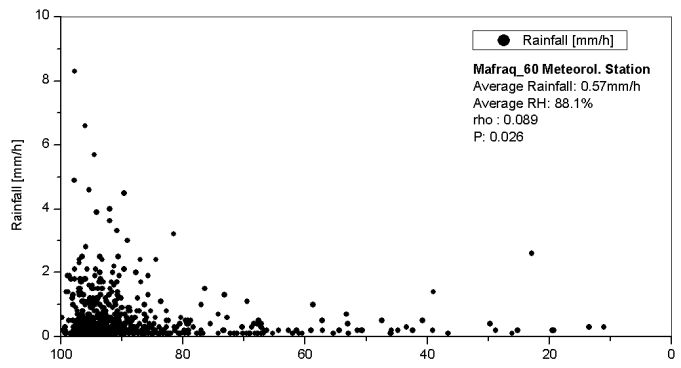

Title Page

Abstract Introduction

Conclusions

References

Relative Humidity [\%]

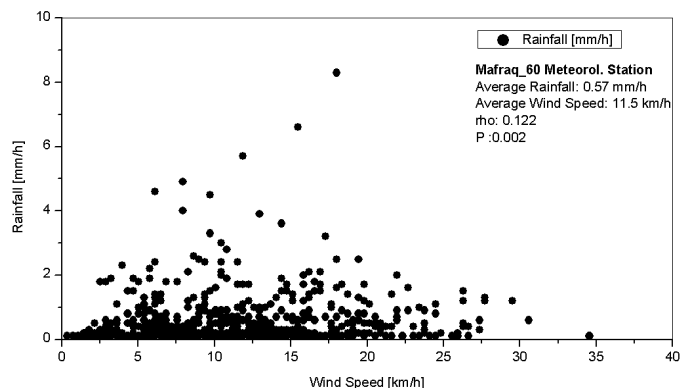

Wind Speed [km/h]

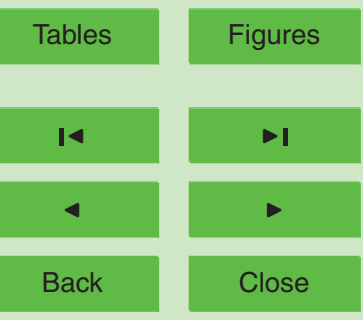

Full Screen / Esc

Printer-friendly Version

Fig. 8. Comparison between hourly rainfall rate with air temperature, relative humidity and wind speed from Mafraq_60 meteorological station (2004-2006). 


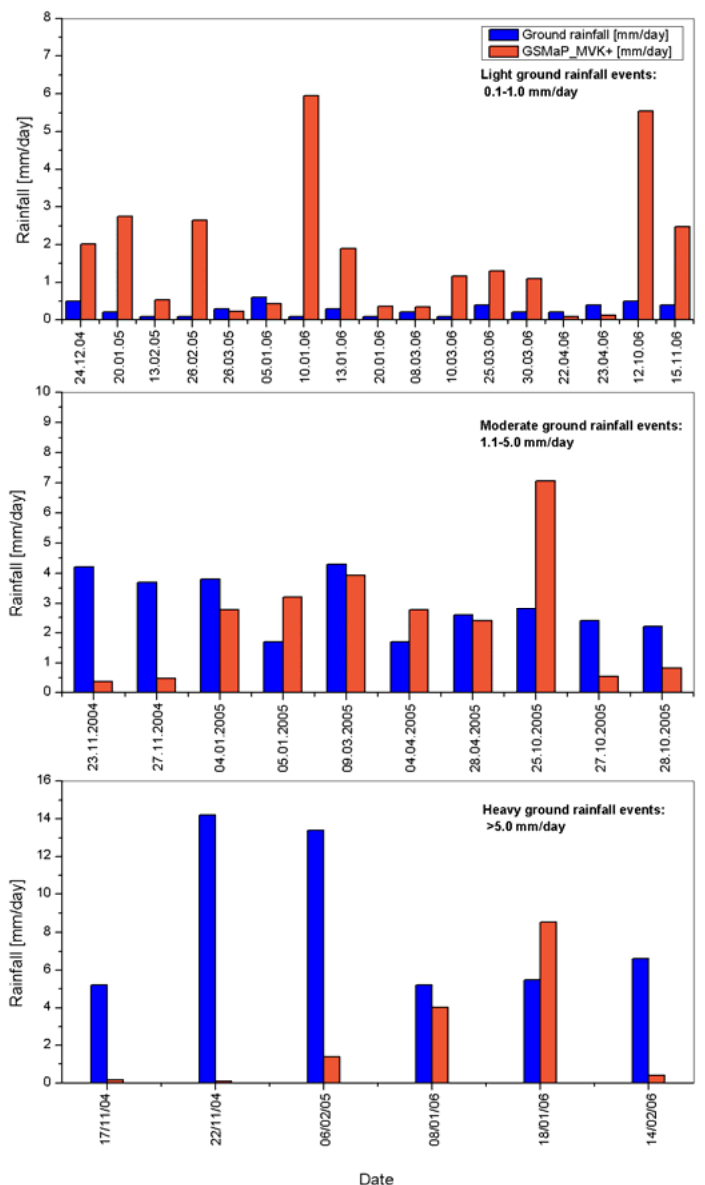

Fig. 9. The daily rainfall rates at the ground and their estimates by GSMaP_MVK+ from Mafraq_60 (2004-2006).

\section{HESSD}

$8,1665-1704,2011$

\section{Rainfall estimation over the Wadi Dhuliel arid catchment \\ E. Abushandi and \\ B. Merkel}

\section{Title Page}

\section{Abstract}

Introduction

Conclusions

References

Tables

Figures

14

-I

4

Back

Close

\section{Full Screen / Esc}

Printer-friendly Version

Interactive Discussion 


\section{HESSD}

$8,1665-1704,2011$
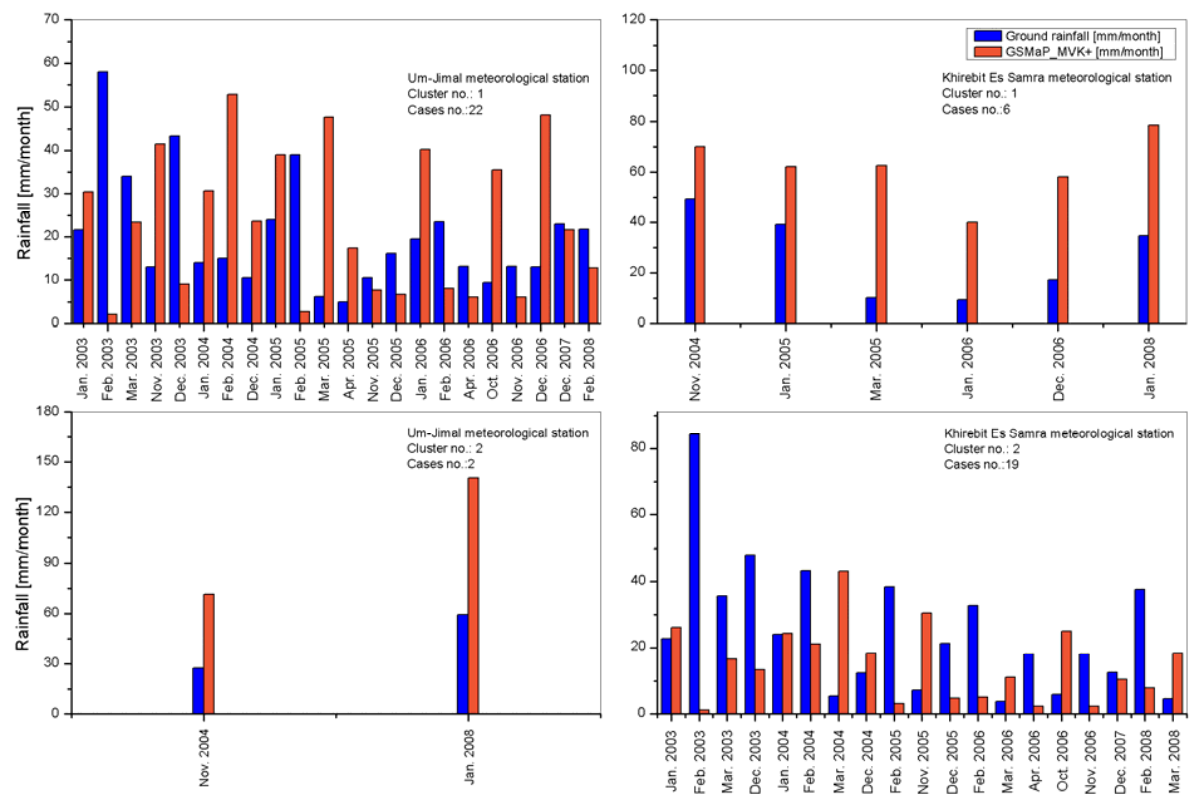

Date

Date

Fig. 10. The monthly rainfall rates monitored at ground and their estimates by GSMaP_MVK+ from Um-Jimal metrological station (left) and Khirebit Es Samra metrological station (right) (2003-2008).

Rainfall estimation over the Wadi Dhuliel arid catchment

E. Abushandi and

B. Merkel

Title Page

Abstract

Introduction

Conclusions

References

Tables

Figures

14

- I

4

Back

Close

Full Screen / Esc

Printer-friendly Version

Interactive Discussion 


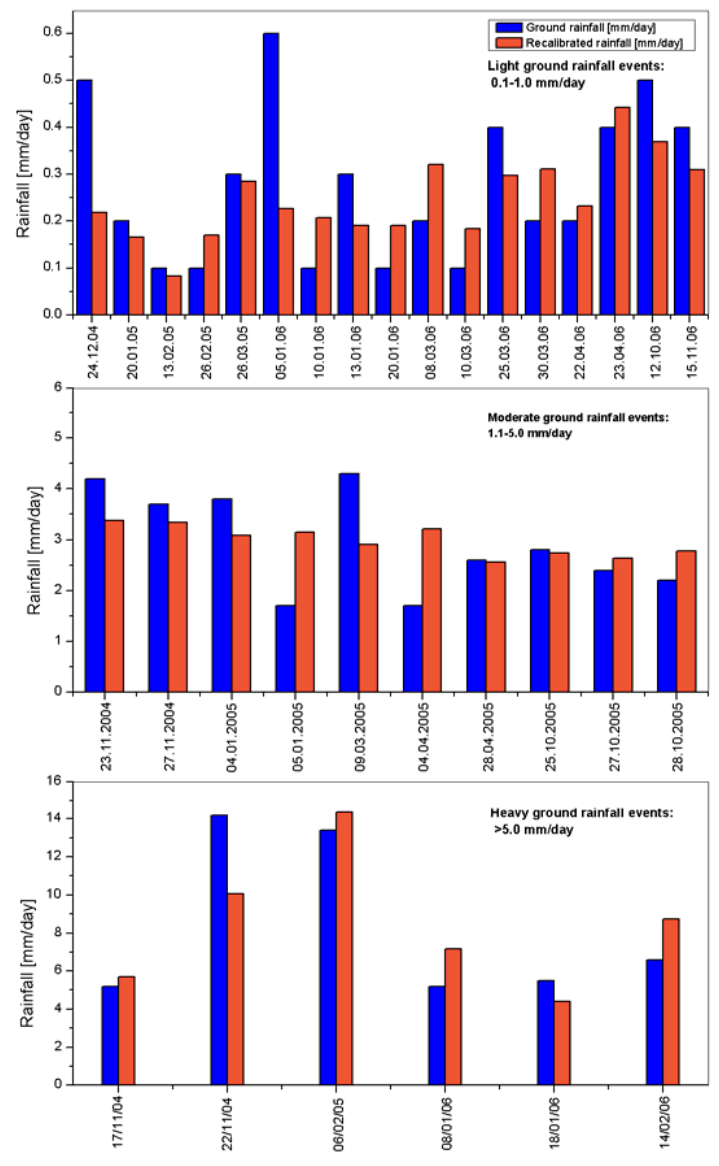

Date

Fig. 11. Comparison between daily adjusted rainfall rates from temperature, relative humidity, and GSMaP_MVK + records with ground rainfall rates obtained from Mafraq_60 meteorological station (2004-2006).

HESSD

$8,1665-1704,2011$

Rainfall estimation over the Wadi Dhuliel arid catchment

E. Abushandi and

B. Merkel

Title Page

Abstract

Introduction

Conclusions

References

Tables

Figures

14

$>$ I

4

Back

Close

Full Screen / Esc

Printer-friendly Version

Interactive Discussion 


\section{HESSD}

$8,1665-1704,2011$
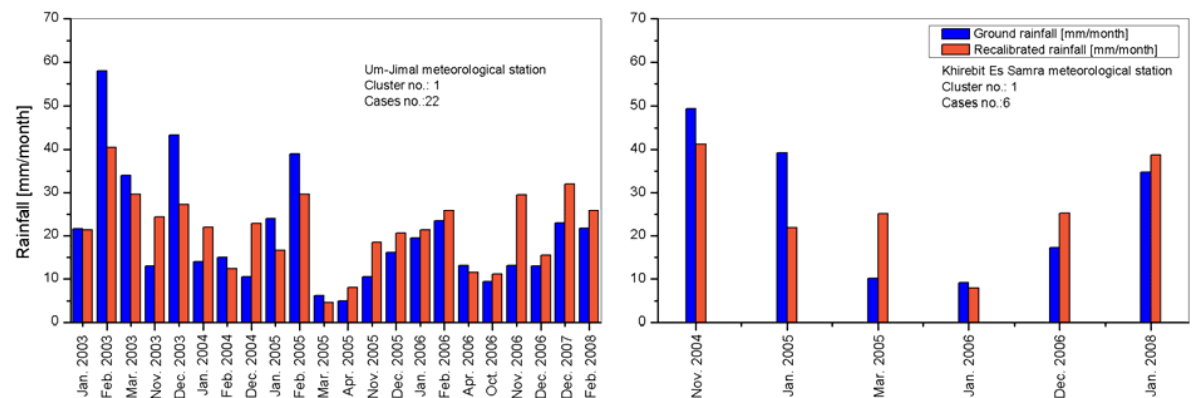

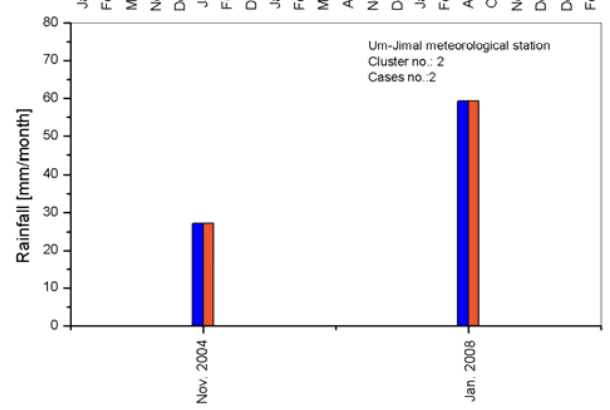

Date

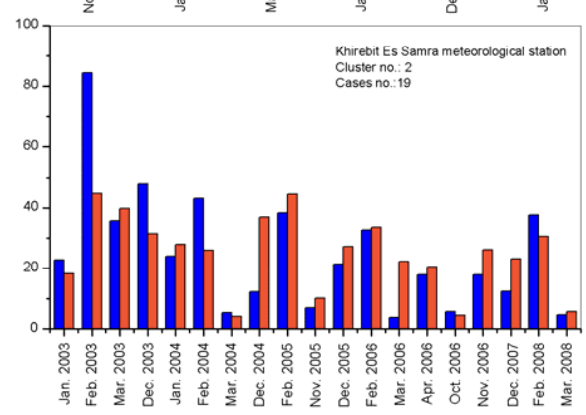

Date

Fig. 12. Comparison between monthly adjusted rainfall rates from temperature, wind speed, and GSMaP_MVK + records with ground rainfall rates obtained from Um-Jimal metrological station (left) and Khirebit Es Samra metrological station (right) (2003-2008).

Rainfall estimation over the Wadi Dhuliel arid catchment

E. Abushandi and

B. Merkel

Title Page

Abstract

Introduction

Conclusions

References

Tables

Figures

14

$\rightarrow$

4

Back

Close

Full Screen / Esc

Printer-friendly Version

Interactive Discussion 

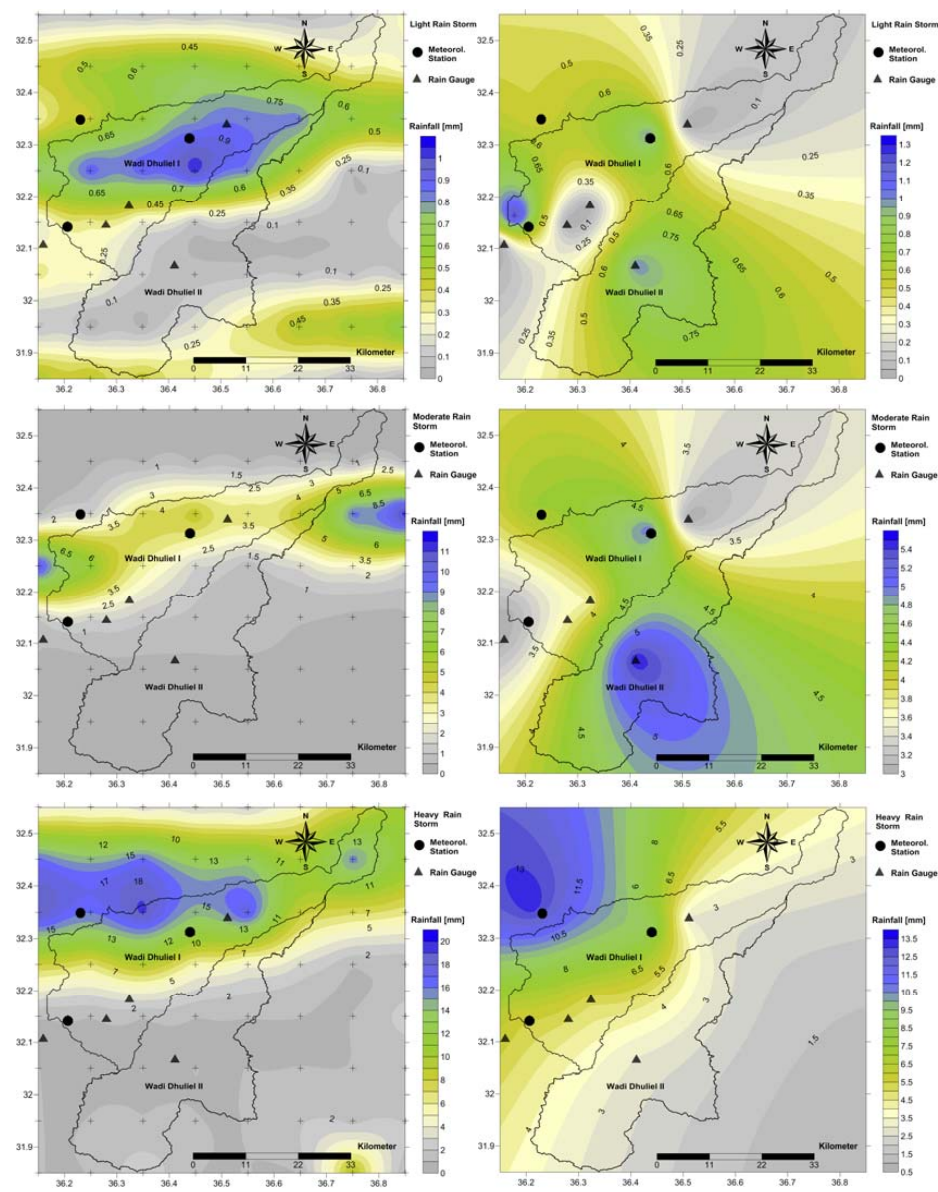

Fig. 13. Spatial comparison of daily rainfall between re-calibrated GSMaP_MVK+ estimates (left) and eight ground rainfall station records (right) using IDW method, light storm in 24 December 2004, moderate storm in 9 March 2005, and heavy storm in 6 February 2005.

HESSD

$8,1665-1704,2011$

\section{Rainfall estimation over the Wadi Dhuliel arid catchment}

E. Abushandi and

B. Merkel

\section{Title Page}

Abstract

Conclusions

\section{Tables}

I

14

$\triangleleft$

Back

\section{Full Screen / Esc}

Printer-friendly Version 


\section{HESSD}

8, 1665-1704, 2011
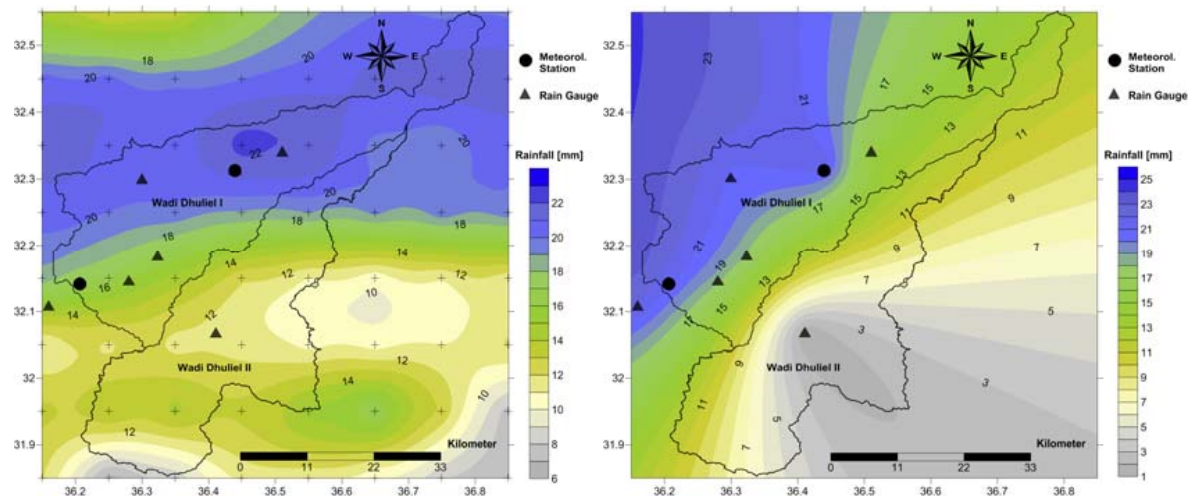

Fig. 14. Spatial comparison of mean monthly rainfall between adjusted GSMaP_MVK+ estimates (left) and eight ground rainfall stations records (right) using IDW method, an example from January 2003.

\section{Rainfall estimation over the Wadi Dhuliel arid catchment \\ E. Abushandi and \\ B. Merkel}

Title Page

Abstract Introduction

Conclusions

References

Tables

Figures

14

4

Back

Full Screen / Esc

Printer-friendly Version

Interactive Discussion 
HESSD

$8,1665-1704,2011$

\section{Rainfall estimation over the Wadi Dhuliel arid catchment \\ E. Abushandi and
B. Merkel
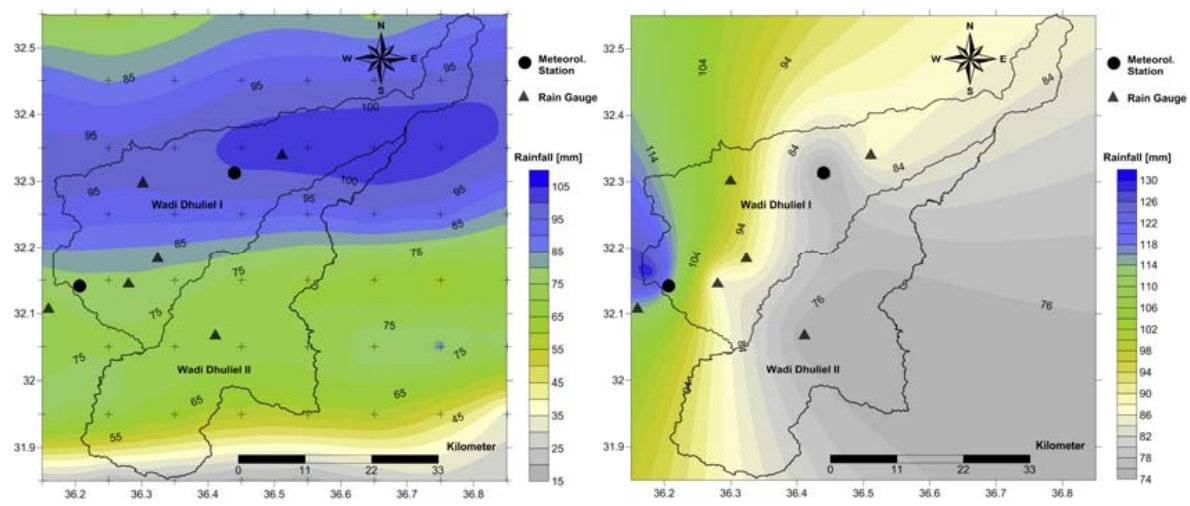

Fig. 15. Spatial comparison of average annual rainfall between adjusted GSMaP_MVK+ estimates (left) and eight ground rainfall stations records (right) using IDW, an example from 2004.

\section{Title Page}

\section{Abstract}

Conclusions

Tables

14

4

Back
Introduction

References

Figures

$>$ I

$>$

Close
Full Screen / Esc

Printer-friendly Version

Interactive Discussion 


\section{HESSD}

8, 1665-1704, 2011

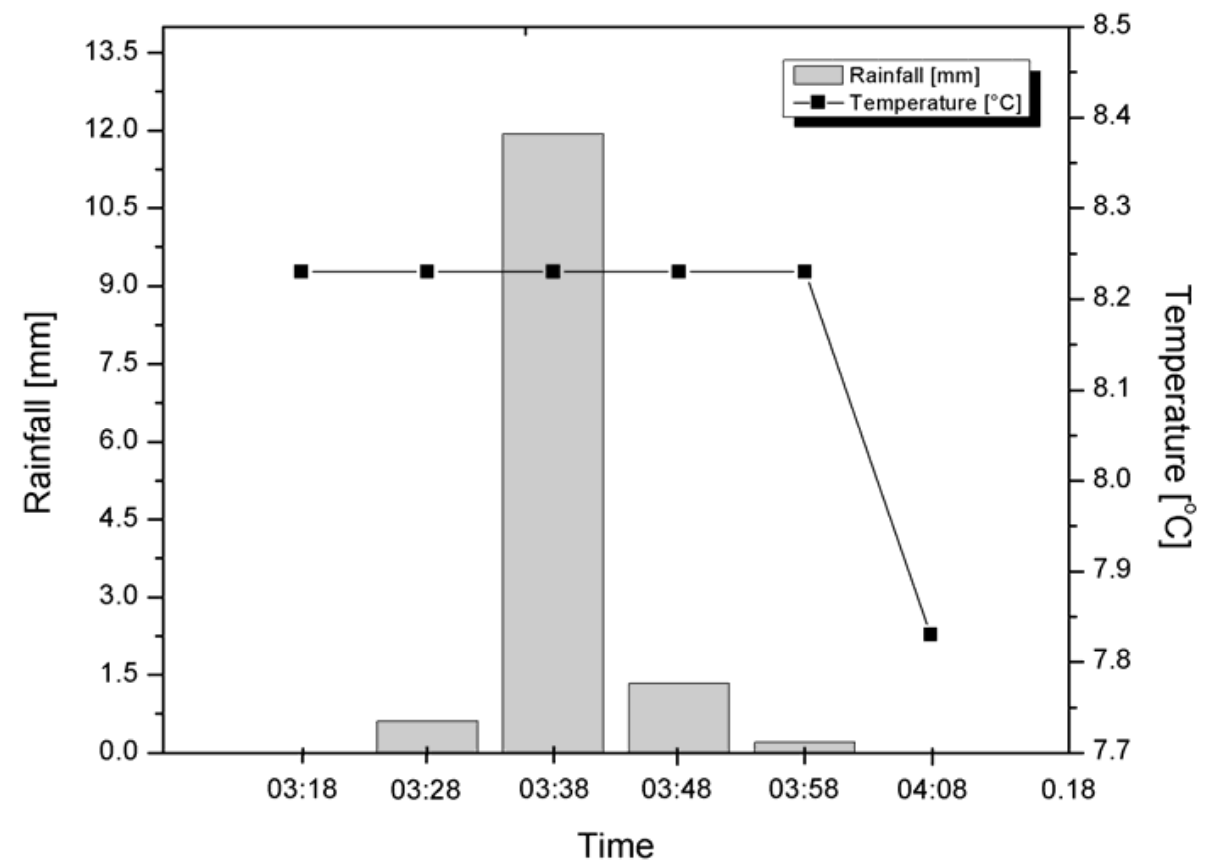

\section{Rainfall estimation over the Wadi Dhuliel arid catchment \\ E. Abushandi and \\ B. Merkel}

Title Page

Abstract

Introduction

Conclusions

References

Tables

Figures

14

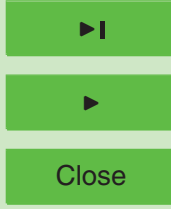

Back

Full Screen / Esc

Printer-friendly Version

Interactive Discussion 